Relative Abundance and Distribution of Fishes and Crayfish at Ash Meadows National Wildlife Refuge, Nye County, Nevada, 2010-11

Open-File Report 2012-1141 



\section{Relative Abundance and Distribution of Fishes and Crayfish at Ash Meadows National Wildlife Refuge, Nye County, Nevada, 2010-11}

By G. Gary Scoppettone, Danielle M. Johnson, Mark E. Hereford, Peter Rissler, Mark Fabes, Antonio Salgado, and Sean Shea

Open-File Report 2012-1141

U.S. Department of the Interior U.S. Geological Survey 


\section{U.S. Department of the Interior \\ KEN SALAZAR, Secretary}

\section{U.S. Geological Survey \\ Marcia K. McNutt, Director}

U.S. Geological Survey, Reston, Virginia: 2012

For more information on the USGS-the Federal source for science about the Earth, its natural and living resources, natural hazards, and the environment-visit http://www.usgs.gov or call 1-888-ASK-USGS

For an overview of USGS information products, including maps, imagery, and publications, visit $h$ ttp://www.usgs.gov/pubprod

To order this and other USGS information products, visit $h t t p: / / s t o r e . u s g s . g o v$

Suggested citation:

Scoppettone, G.G., Johnson, D.M., Hereford, M.E., Rissler, Peter, Fabes, Mark, Salgado, Antonio, and Shea, Sean, 2012, Relative abundance and distribution of fishes and crayfish at Ash Meadows National Wildlife Refuge, Nye County, Nevada, 2010-11: U.S. Geological Survey Open-File Report 2012-1141, $44 \mathrm{p}$.

Any use of trade, product, or firm names is for descriptive purposes only and does not imply endorsement by the U.S. Government.

Although this report is in the public domain, permission must be secured from the individual copyright owners to reproduce any copyrighted material contained within this report. 


\section{Contents}

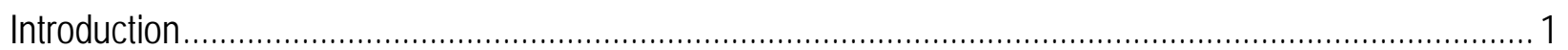

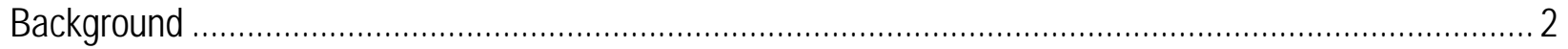

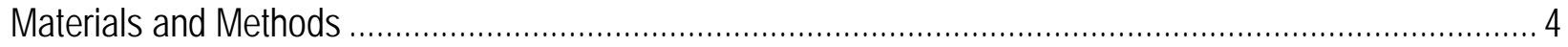

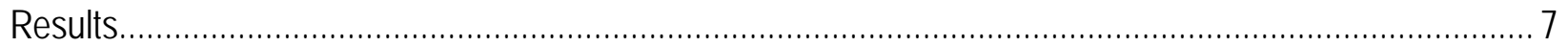

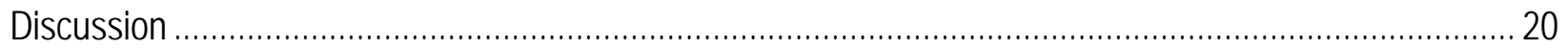

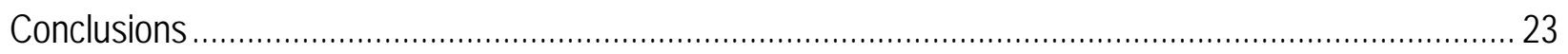

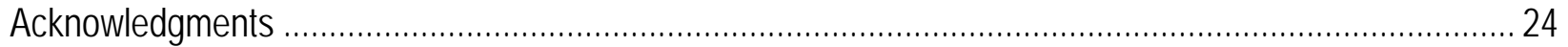

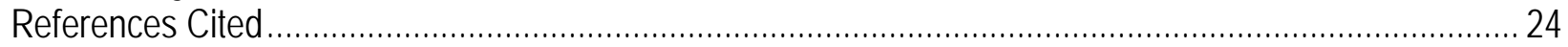

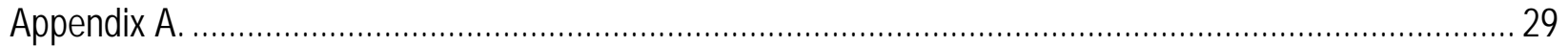

\section{Figures}

Figure 1. Aerial photograph of Ash Meadows National Wildlife Refuge showing sampling stations in fall 2010 (741), winter 2011 (156), and spring 2011 (744), Nye County, Nevada....

Figure 2. Relative abundance and distribution of Ash Meadows Amargosa pupfish throughout Ash Meadows National Wildlife Refuge, Nevada, fall 2010

Figure 3. Relative abundance and distribution of Ash Meadows Amargosa pupfish in Fairbanks, Soda, Rogers, and Longstreet Springs Ash Meadows, National Wildlife Refuge, Nevada, winter 2011 9

Figure 4. Relative abundance and distribution of Ash Meadows Amargosa pupfish throughout Ash Meadows National Wildlife Refuge, Nevada, spring 2011 10

Figure 5. Relative abundance and distribution of Ash Meadows speckled dace throughout Ash Meadows National Wildlife Refuge, Nevada, fall 2010.

Figure 6. Relative abundance and distribution of Ash Meadows speckled dace in Fairbanks, Soda, Rogers, and Longstreet Springs Ash Meadows National Wildlife Refuge, Nevada, winter 2011....... 12 Figure 7. Relative abundance and distribution of Ash Meadows speckled dace throughout Ash Meadows National Wildlife Refuge, Nevada, spring 2011 13

Figure 8. Relative abundance and distribution of pupfish in North Scruggs, South Scruggs, Marsh, and School Springs, Ash Meadows National Wildlife Refuge, Nevada, fall 2010 and spring $2011 .$. 15 


\section{Tables}

Table 1. Seasonal catches of fishes, bullfrog, and crayfish at the Northern Springs of the Ash Meadows National Wildlife Refuge, Nevada, fall 2010 and spring 2011.

Table 2. Seasonal catches of fishes, bullfrogs, and crayfish in the Warm Springs Complex of the

Ash Meadows National Wildlife Refuge, Nevada, fall 2010 and spring 2011.

Table 3. Seasonal catches of fishes, bullfrogs, and crayfish at the Southern Springs of the

Ash Meadows National Wildlife Refuge, Nevada, fall 2010 and spring 2011.

\section{Conversion Factors}

\begin{tabular}{lcl}
\hline \multicolumn{1}{c}{ Multiply } & By & \multicolumn{1}{c}{ To obtain } \\
\hline centimeter $(\mathrm{cm})$ & 0.3937 & inch (in.) \\
millimeter $(\mathrm{mm})$ & 0.03937 & inch (in.) \\
meter $(\mathrm{m})$ & 3.281 & foot (ft) \\
kilometer $(\mathrm{km})$ & 0.6214 & mile (mi) \\
cubic meter per second $\left(\mathrm{m}^{3} / \mathrm{s}\right)$ & 70.07 & acre-foot per day (acre-ft/d) \\
\hline
\end{tabular}

Temperature in degrees Celsius $\left({ }^{\circ} \mathrm{C}\right)$ may be converted to degrees Fahrenheit $\left({ }^{\circ} \mathrm{F}\right)$ as follows:

${ }^{\circ} \mathrm{F}=\left(1.8 x^{\circ} \mathrm{C}\right)+32$. 


\section{Relative Abundance and Distribution of Fishes and Crayfish at Ash Meadows National Wildlife Refuge, Nye County, Nevada, 2010-11}

By G. Gary Scoppettone, Danielle M. Johnson, Mark E. Hereford, Peter Rissler, Mark Fabes, Antonio Salgado, and Sean Shea

\section{Introduction}

Ash Meadows National Wildlife Refuge (AMNWR) was established by the U.S. Fish and Wildlife Service (with the assistance of The Nature Conservancy) in 1984 to protect one of the highest concentrations of endemic flora and fauna in North America (Pister, 1985; Sada, 1990). Prior to federal acquisition, Ash Meadows had been anthropogenically altered, and non-native species had been introduced to the detriment of native species; reports and published literature document the negative effects to the Ash Meadows flora and fauna (Deacon and others, 1964; U.S. Department of the Interior, 1971; Landye, 1973; Pister, 1974; Soltz and Naiman, 1978; Taylor, 1980; Williams and others, 1985; Williams and Sada, 1985; Baugh and others, 1986; Hershler and Sada, 1987; Knight and Clemmer, 1987; Sada, 1990; Deacon and Williams, 1991; Scoppettone and others, 2005; Kennedy and others, 2006). Such activities led to the extinction of the endemic Ash Meadows poolfish (Empetrichthyes merriami) (Miller, 1961; Soltz and Naiman, 1978), and subsequently the federal government listed three local endemic fish as endangered pursuant to the Endangered Species Act (U.S. Fish and Wildlife Service, 1989)_Warm springs pupfish (Cyprinodon nevadensis pectoralis), Ash Meadows Amargosa pupfish (Cyprinodon nevadensis mionectes), and Ash Meadows speckled dace (Rhinichthys osculus nevadensis).

Public ownership of a large portion of Ash Meadows provided the opportunity to restore the landscape to some semblance of its historical condition. Elimination of invasive aquatic species may be more difficult than landscape restoration, and their persistence can cause additional native fish decline or extirpation (Taylor and others, 1984; Moyle and others, 1986; Miller and others, 1989; Minckley and Deacon, 1991; Olden and Poff, 2005). Chemical treatment to remove invasive fishes is often unsuccessful (Meffe, 1983; Rinne and Turner, 1991; Meronek and others, 1996). In Ash Meadows, there has been some success in chemical eradication of localized populations of largemouth bass (Micropterus salmoides) and black bullhead (Ameiurus melas) (St. George, 1998, 1999; Weissenfluh, 2008b), as well as convict cichlid (Archocentrus nigrofasciatus) and sailfin molly (Poecilia latipinna) (Weissenfluh, 
2008a). However, there has been less success in removing western mosquitofish (Gambusia affinis) from Ash Meadows's larger spring systems, and sailfin molly maintains strongholds in several spring systems (Scoppettone and others, 2011b). Perhaps the more destructive invasive species are two invertebrates: red swamp crayfish (Procambarus clarkii) and red-rim melania (Melanoides tuberculata). Following the appearance of red swamp crayfish within the Warm Springs Complex, Warm Springs pupfish was believed to be extirpated from one spring system (St. George, 2000) and near extirpation in two others (Darrick Weissenfluh, Ash Meadows National Wildlife Refuge, oral commun., 2008, 2011). Crayfish also were demonstrated to greatly suppress the Bradford Springs population of Ash Meadows speckled dace population (McShane and others, 2004). Red-rim melania is known to displace native snail populations (Mitchell and others, 2007), and has been implicated as an agent of extinction of native Ash Meadows spring-snails (Donald Sada, Desert Research Institute, oral commun., 2011). Both invasive invertebrates are difficult to control or eradicate (Mitchell and others, 2007; Freeman and others, 2010).

Habitat restoration that favors native species can help control non-native species (McShane and others, 2004; Scoppettone and others, 2005; Kennedy and others, 2006).

Restoration of Carson Slough and its tributaries present an opportunity to promote habitat types that favor native species over non-natives. Historically, the majority of Ash Meadows spring systems were tributaries to Carson Slough. In 2007 and 2008, a survey of Ash Meadows spring systems was conducted to generate baseline information on the distribution of fishes throughout AMNWR (Scoppettone and others, 2011b). In this study, we conducted a follow-up survey with emphasis on upper Carson Slough. This permitted us to gauge the early effects of spring system restoration on fish populations and to generate further baseline data relevant to future restoration efforts.

\section{Background}

Dudley and Larson (1976) described the Ash Meadows spring systems as emerging in three groups: northern, central, and southern spring systems. Their grouping is based on spring connectivity: Fairbanks, Soda, Rogers, Longstreet, Five, and Cold Springs make up Northern Springs; School, North Indian, South Indian, Marsh, North Scruggs, South Scruggs, and Crystal Springs make up the Central Springs; and Kings Pool, Point of Rocks, Jack Rabbit, Big, Forest, Tubbs, and Bradford Springs make up the Southern Springs. Our grouping of spring systems is similar to that of Dudley and Larson (1976), but is taxonomically influenced-we include Crystal Spring with the Southern Springs, and we refer to the Central Springs as the Warm Springs Complex. Our grouping allows us to better distinguish Warm Springs and Ash Meadows pupfish habitats. 


\section{Northern Springs}

Historically, the Northern Springs flowed into a common channel (Carson Slough) as shown in the Mount Diablo Meridian (Department of Interior General Land office, February 16, 1887). Prior to spring system restoration, the outflows of the Northern Springs were all earthen ditches conveying water for irrigation. Over time, water conveyance channels had become clogged with emergent vegetation causing channels to overflow, creating marsh lands within several hundred meters of spring discharge points. Restoration of the Northern Springs is targeted toward conveying spring discharge within a well-defined channel mimicking the historical course (Darrick Weissenfluh, Ash Meadows National Wildlife Refuge, oral commun., 2011). Our 2011 survey was conducted during phase 2 of pre- and post-restoration of Fairbanks Spring system. In phase 1 completed in March 2010, a stream channel was constructed from Fairbanks spring-pool to $4 \mathrm{~km}$ downstream and its discharge formed a shallow marsh. In phase 2 completed in November 2010, Fairbanks Spring was connected, with a well-defined channel, to Longstreet and Rogers Springs. To avoid confusion in comparing seasonal fish distribution created by changes to the Northern Spring systems, we named the reach of stream receiving water from Longstreet and Rogers Springs and southward to join Fairbanks Springs and extending to Peterson Reservoir as "Carson Slough.” In phase 1, this reach received water only from Longstreet and Rogers Springs, drained from a common marsh. In phase 2, Carson Slough also received water from Fairbanks Spring at about the slough's midpoint. In addition to changing stream courses, the Fairbanks Spring system received 98 Ash Meadows speckled dace on April 14-15, 2010, and another 20 dace on August 19, 2010 (Cristi Baldino, Ash Meadows National Wildlife Refuge, written commun., 2011).

Soda Spring also was restored following the 2007-08 survey. Prior to restoration, the outflow was marsh habitat discharging into Fairbanks Spring, and after restoration, a welldefined channel approximately $300 \mathrm{~m}$ in length discharged into a shallow marsh south of the Soda spring-pool. A total of 21 speckled dace were introduced between April 3 and 18, 2011 (Cristi Baldino, Ash Meadows National Wildlife Refuge, written commun., 2011).

Restoration of Longstreet, Rogers, and Cold Springs is in the design stage. As part of restoration, sailfin mollies were eliminated from the Longstreet Spring system prior to the spring survey. This was part of a Nevada Department of Wildlife rotenone project conducted from February 15-16, 2011 (Kevin Guadalupe, Great Basin Institute, written commun., 2012). Longstreet Spring was the only site in the Northern Spring area known to harbor sailfin molly (Scoppettone and others, 2011b).

\section{Warm Springs Complex}

The Warm Springs Complex consists of several warm $\left(30-33.5^{\circ} \mathrm{C}\right)$, low discharge springs $\left(<0.028 \mathrm{~m}^{3} / \mathrm{s}\right)$ sufficiently isolated to harbor one of the six subspecies of Amargosa pupfish, Warm Springs Amargosa pupfish (Miller, 1948). One small population in Mexican Spring was lost in 1973 when the spring dried (Yoakum and others, 1976). Because Warm Springs pupfish exist in such small and low-flow habitat, they are more susceptible to non-native invaders, such as crayfish and mosquitofish.

During the current study, the Indian Spring system was undergoing restoration and was not sampled. Other changes since the 2007-08 survey were refuge acquisition of a private land along North Scruggs Spring, allowing us to sample that entire system, and rehabilitation of School Spring, including elimination of mosquitofish and crayfish from that system (Weissenfluh, 2008c, 2010). 


\section{Southern Springs}

Crystal Spring is Ash Meadows largest spring by discharge $\left(0.18 \mathrm{~m}^{3} / \mathrm{s}\right)$. Much of the flow is conveyed in concrete channels constructed before federal acquisition. A diagram of the Crystal Spring channel system appears in Scoppettone and others (1995). The channels are in a state of decay, and water has broken through at several locations. During this study, water was being diverted to Crystal Reservoir, and Crystal Marsh and Horseshoe Marsh, also referred to as Lower Crystal Reservoir and Horseshoe Reservoir, respectively.

No restoration was initiated in the Southern Springs area since the 2007-08 survey by Scoppettone and others (2011b). However, there was a substantial change in vegetation along the Jackrabbit Spring system with coyote willow (Salix exigua) proliferating along the stream reach restored in 2006, and common reed (Phragmites sp.) spreading several hundred meters downstream of the restoration site.

\section{Materials and Methods}

We followed Scoppettone and others (2011b) and used Geographic Information Systems (GIS) using the National Agricultural Imagery Program (NAIP) to trace stream channels and to determine locations of sampling stations. In this study, comprehensive surveys of Ash Meadows spring systems were conducted in the fall 2010 and spring 2011. We also surveyed the larger Northern Springs in the winter 2011. There were 741 and 744 established sampling stations for the fall and spring surveys, respectively, and 156 for the winter survey. (fig. 1). The lowermost reach of the Fairbanks Spring outflow was realigned to flow into Carson Slough between fall 2010 and winter 2011 (fig. 1). Coordinates for each station were created using North American Datum (NAD) 83 decimal degrees longitude/latitude and downloaded into Garmin Global Positioning System (GPS) units. These units typically are accurate within a $2 \mathrm{~m}$ radius of a specific station. GIS also was used to illustrate seasonal distribution and relative abundance of fishes in each spring system. Data collected during each sampling period were used to develop species-specific GIS maps, which display range and densities.

We used standard Gee (1/8-in. mesh) and modified minnow traps and followed the same sampling protocol described by Scoppettone and others (2011b). Most traps were set in the afternoon and checked the following morning. Shorter sets, placed in the morning and checked 3 -h later, were used in areas with high fish densities, high crayfish densities, spring pools, and areas with water temperatures greater than $29^{\circ} \mathrm{C}$ (to prevent fish mortality). Floats were used in spring-pools to set a trap at mid-water and a trap near the surface, as well as four benthic sets to sample the entire water column. Fish were identified to species and 10-20 individuals from each trap were measured to fork length (FL). Water temperature, using pocket thermometers, and depth measurements were taken at each station.

Relative abundance and distribution are illustrated using two methods: (1) total fish captured in each system and major habitat type (springhead, spring-pool, outflow, marsh, and reservoir) is shown by season in tabular form; and (2) trap-specific distribution and abundance using combined seasonal data are presented using GIS-generated maps. 


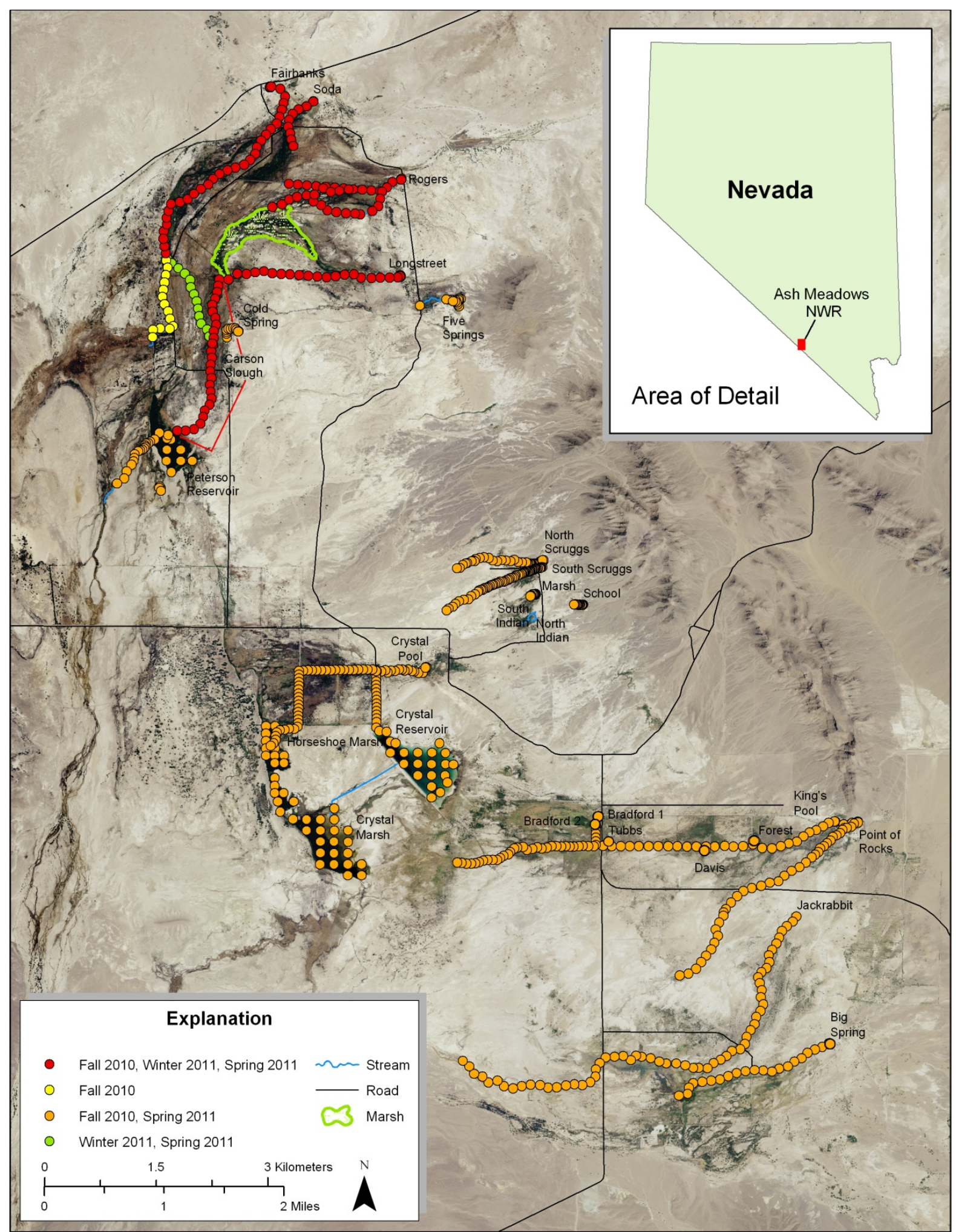

Figure 1. Aerial photograph of Ash Meadows National Wildlife Refuge showing sampling stations in fall 2010 (741), winter 2011 (156), and spring 2011 (744), Nye County, Nevada. 


\section{Results}

\section{Northern Springs}

Pupfish were numerous and widespread in the restored habitats of Fairbanks and Soda Springs, and Carson Slough. In Fairbanks Spring system, pupfish were captured in greatest frequency and over a broader area in fall 2010 and spring 2011 than in winter 2011 (table 1, figs. 2 and 4). The greatest number of pupfish was captured from Carson Slough, close to Peterson Reservoir, in winter (fig. 3). The greatest number of speckled dace was captured in winter from Fairbanks outflow $(n=236)$ and from Carson Slough $(n=13)$ (table 1). Speckled dace distribution was broadest in spring 2011 (figs. 5-7), with two dace captured in Longstreet stream and another two in Peterson stream. Water velocity at four stations in Fairbanks stream and five stations in Carson Slough was too rapid to set minnow traps; we suspect that we would have captured dace at these stations as well. There were no consistent trends in pupfish length between spring-pools and stream outflows among seasons (table A1). Among the Northern Springs, pupfish in Five Springs generally were the smallest (17-51 mm). The larger crayfish generally occurred in the spring systems with greater discharge (Fairbanks, Rogers, and Longstreet Springs). American bullfrog (Rana catesbeiana) also was captured in Fairbanks, Soda, Rogers and Longstreet Spring systems (table 1 ).

In the Northern Springs area, sailfin molly was only present in the Longstreet Spring system, with few captures in the spring-pool and outflow stream in fall 2010 and winter 2011 (table 1, figs. A1-A2). Following the February 2011 chemical treatment aimed at eliminating sailfin molly from the Longstreet Spring system, no sailfin mollies were captured in spring 2011 (fig. A3). Mosquitofish were more widespread than sailfin molly (figs. A4-A6), but captures generally were low for the Fairbanks and Longstreet Spring systems in winter and spring. Cold Spring was the only Northern Spring system in which no mosquitofish was captured. Captures for mosquitofish were highest in the Rogers Spring system, which also had the highest captures of crayfish for the three seasons sampled. 
Table 1. Seasonal catches of fishes, bullfrog, and crayfish at the Northern Springs of the Ash Meadows National Wildlife Refuge, Nevada, fall 2010 and spring 2011.

[Winter 2011—only Fairbanks, Soda, Rogers and Longstreet Springs were sampled. Spring locations are shown in figure 1. Species: CYMI, Ash Meadows Amargosa pupfish; CYPE, Warm Springs Amargosa pupfish; GAAF, Mosquitofish; LECY, Green Sunfish; MISA, Largemouth Bass; POLA, Sailfin Molly; PRCL, Red Swamp Crayfish; RACA, Bullfrog; RHON, Ash Meadows speckled dace]

\begin{tabular}{|c|c|c|c|c|c|c|c|c|c|c|}
\hline \multirow{2}{*}{ System } & \multirow{2}{*}{ Season } & \multicolumn{9}{|c|}{ Species } \\
\hline & & CYMI & CYPE & RHON & GAAF & POLA & LECY & MISA & RACA & PRCL \\
\hline \multirow{3}{*}{$\begin{array}{c}\text { Fairbanks spring- } \\
\text { pool }\end{array}$} & Fall 2010 & 426 & - & - & - & - & - & - & - & 62 \\
\hline & Winter 2011 & 272 & - & - & - & - & - & - & - & - \\
\hline & Spring 2011 & 417 & - & - & - & - & - & - & - & 31 \\
\hline \multirow{3}{*}{ Fairbanks stream } & Fall 2010 & 1,264 & - & 120 & 149 & - & - & - & - & 41 \\
\hline & Winter 2011 & 880 & - & 236 & 3 & - & - & - & 1 & 72 \\
\hline & Spring 2011 & 2,491 & - & 166 & 5 & - & - & - & 1 & 56 \\
\hline \multirow{3}{*}{ Soda spring-pool } & Fall 2010 & 3 & - & - & 10 & - & - & - & - & 3 \\
\hline & Winter 2011 & - & - & - & - & - & - & - & - & 10 \\
\hline & Spring 2011 & 12 & - & - & 2 & - & - & - & - & 24 \\
\hline \multirow{3}{*}{ Soda stream } & Fall 2010 & 251 & - & - & - & - & - & - & 2 & 41 \\
\hline & Winter 2011 & 417 & - & - & 5 & - & - & - & - & 58 \\
\hline & Spring 2011 & 363 & - & - & 3 & - & - & - & - & 58 \\
\hline \multirow{3}{*}{ Roger spring-pool } & Fall 2010 & 125 & - & - & 66 & - & - & - & 6 & 31 \\
\hline & Winter 2011 & 213 & - & - & 22 & - & - & - & 2 & 8 \\
\hline & Spring 2011 & 227 & - & - & 21 & - & - & - & 10 & 2 \\
\hline \multirow{3}{*}{ Roger stream } & Fall 2010 & 14 & - & - & 205 & - & - & - & - & 150 \\
\hline & Winter 2011 & 58 & - & - & 190 & - & - & - & 1 & 195 \\
\hline & Spring 2011 & 32 & - & - & 97 & - & - & - & - & 176 \\
\hline \multirow{3}{*}{$\begin{array}{l}\text { Longstreet } \\
\text { spring-pool }\end{array}$} & Fall 2010 & 319 & - & - & 5 & 5 & - & - & - & 16 \\
\hline & Winter 2011 & 599 & - & - & 16 & 13 & - & - & 4 & 29 \\
\hline & Spring 2011 & 79 & - & - & 1 & - & - & - & - & 24 \\
\hline \multirow{3}{*}{ Longstreet stream } & Fall 2010 & 27 & - & - & 30 & 1 & - & - & - & 51 \\
\hline & Winter 2011 & 19 & - & - & 20 & 4 & - & - & - & 22 \\
\hline & Spring 2011 & 17 & - & 1 & - & - & - & - & - & 39 \\
\hline \multirow{3}{*}{ Carson Slough } & Fall 2010 & 157 & - & - & 115 & - & - & - & - & 6 \\
\hline & Winter 2011 & 1,449 & - & 13 & 2 & - & - & - & - & 11 \\
\hline & Spring 2011 & 312 & - & 3 & 4 & - & - & - & - & 28 \\
\hline \multirow{2}{*}{$\begin{array}{l}\text { Five Springs } \\
\text { spring-pool }\end{array}$} & Fall 2010 & 24 & - & - & 4 & - & - & - & - & 8 \\
\hline & Spring 2011 & 12 & - & - & - & - & - & - & - & 3 \\
\hline \multirow{2}{*}{$\begin{array}{c}\text { Five Springs } \\
\text { stream }\end{array}$} & Fall 2010 & 6 & - & - & 43 & - & - & - & - & 34 \\
\hline & Spring 2011 & 10 & - & - & 36 & - & - & - & - & - \\
\hline \multirow{2}{*}{ Peterson reservoir } & Fall 2010 & 29 & - & - & 19 & - & - & - & - & 1 \\
\hline & Spring 2011 & 8 & - & - & - & - & - & - & - & - \\
\hline \multirow{2}{*}{ Peterson stream } & Fall 2010 & & & & No water & due to lo & reservoi & level & & \\
\hline & Spring 2011 & 124 & - & 2 & 1 & - & - & - & - & 1 \\
\hline \multirow{2}{*}{ Cold spring } & Fall 2010 & - & - & - & - & - & - & - & - & 21 \\
\hline & Spring 2011 & - & - & - & - & - & - & - & - & 26 \\
\hline \multirow{2}{*}{ Cold stream } & Fall 2010 & 1 & - & - & - & - & - & - & - & 51 \\
\hline & Spring 2011 & 1 & - & - & - & - & - & - & - & 37 \\
\hline \multirow{2}{*}{ Cold pool } & Fall 2010 & - & - & - & - & - & - & - & - & 5 \\
\hline & Spring 2011 & - & - & - & - & - & - & - & - & 18 \\
\hline
\end{tabular}




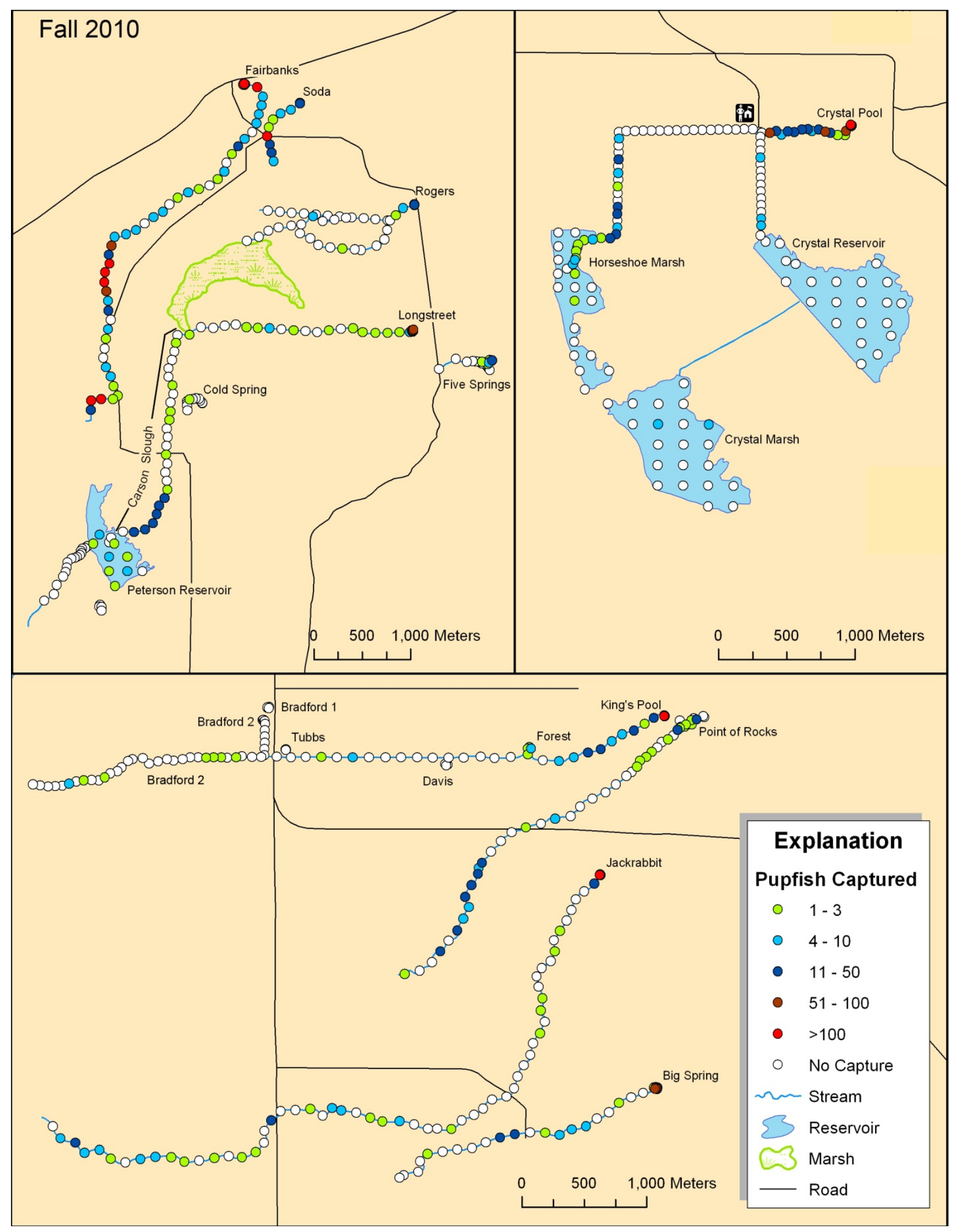

Figure 2. Relative abundance and distribution of Ash Meadows Amargosa pupfish throughout Ash Meadows National Wildlife Refuge, Nevada, fall 2010. 


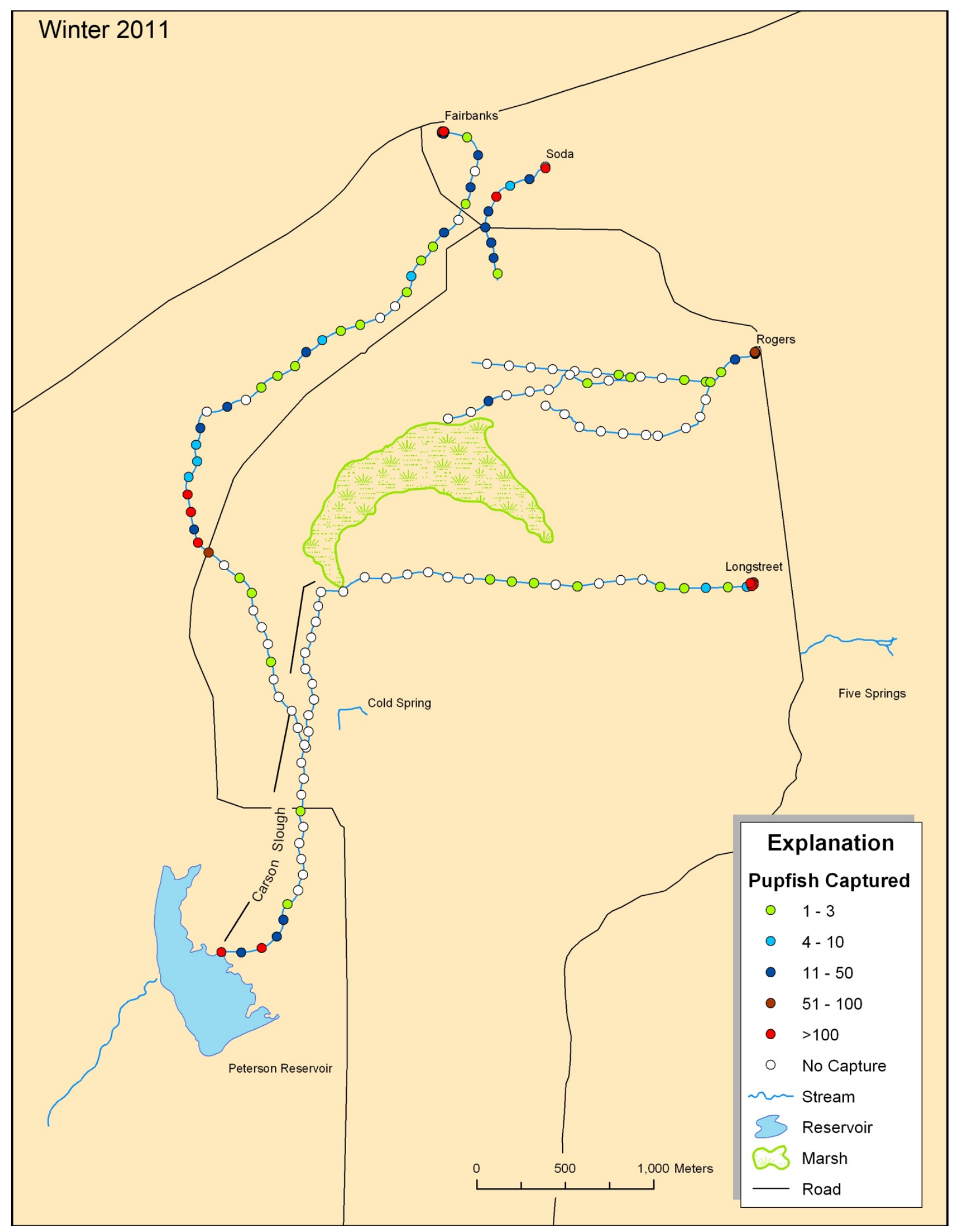

Figure 3. Relative abundance and distribution of Ash Meadows Amargosa pupfish in Fairbanks, Soda, Rogers, and Longstreet Springs Ash Meadows, National Wildlife Refuge, Nevada, winter 2011. 


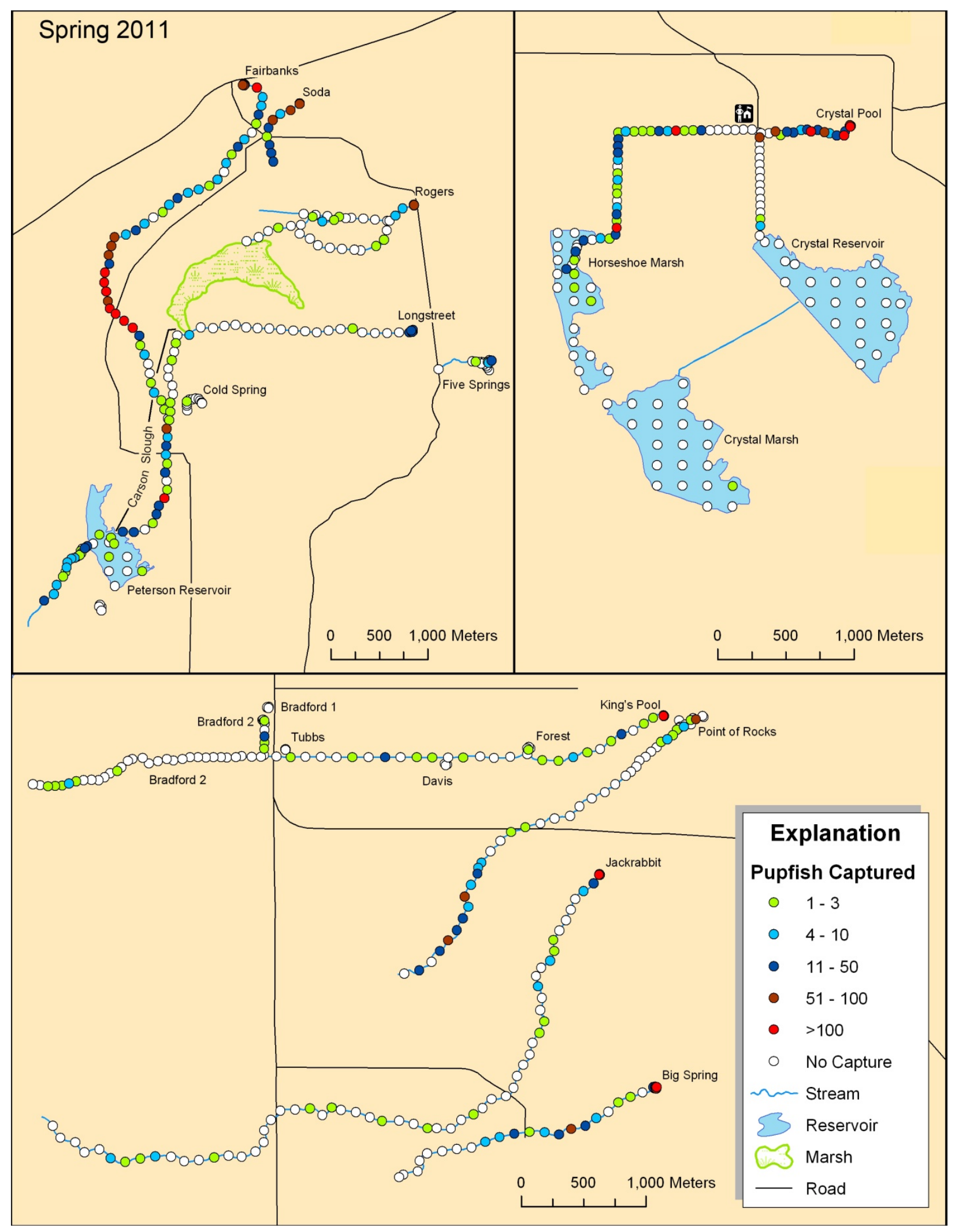

Figure 4. Relative abundance and distribution of Ash Meadows Amargosa pupfish throughout Ash Meadows National Wildlife Refuge, Nevada, spring 2011. 


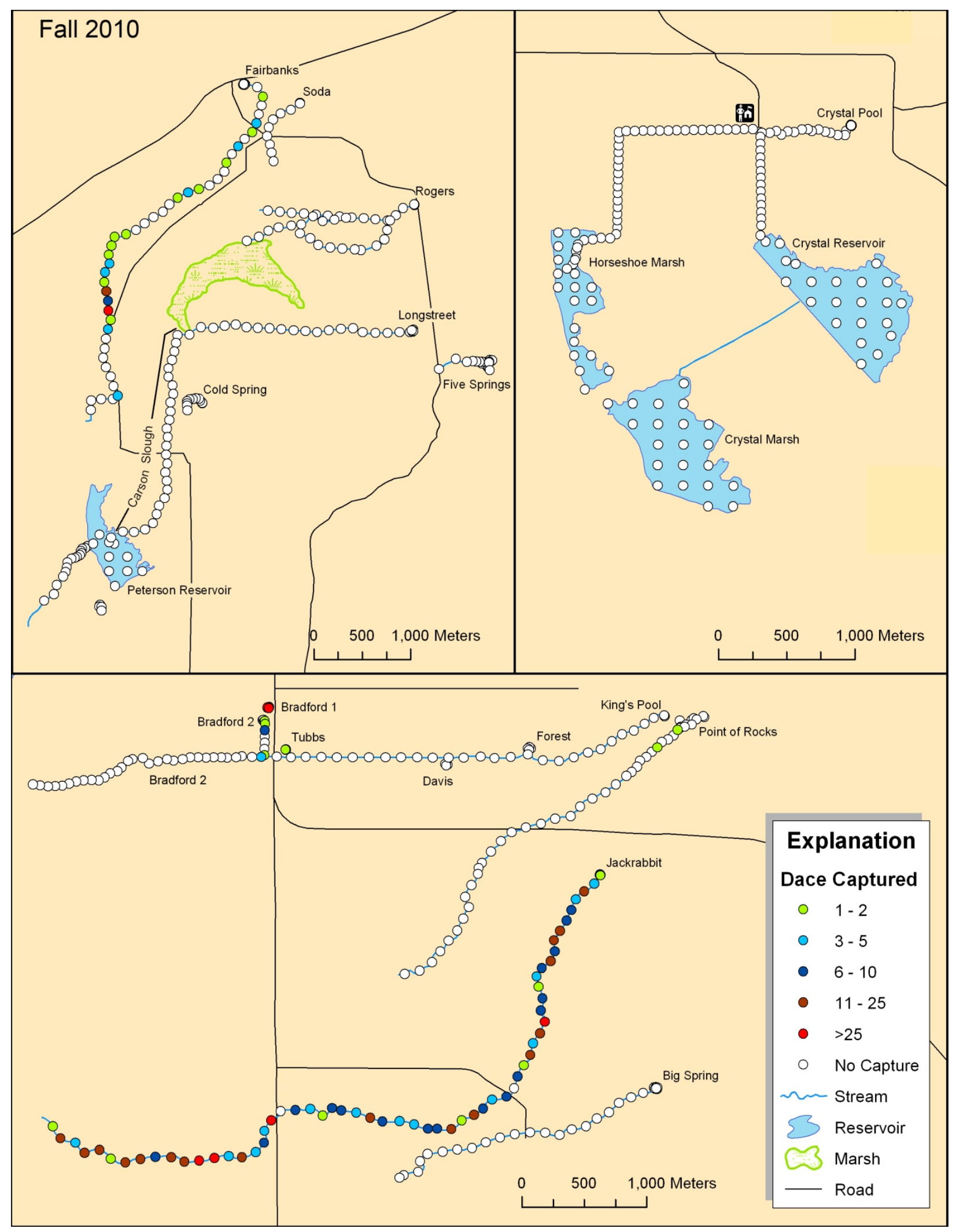

Figure 5. Relative abundance and distribution of Ash Meadows speckled dace throughout Ash Meadows National Wildlife Refuge, Nevada, fall 2010. 


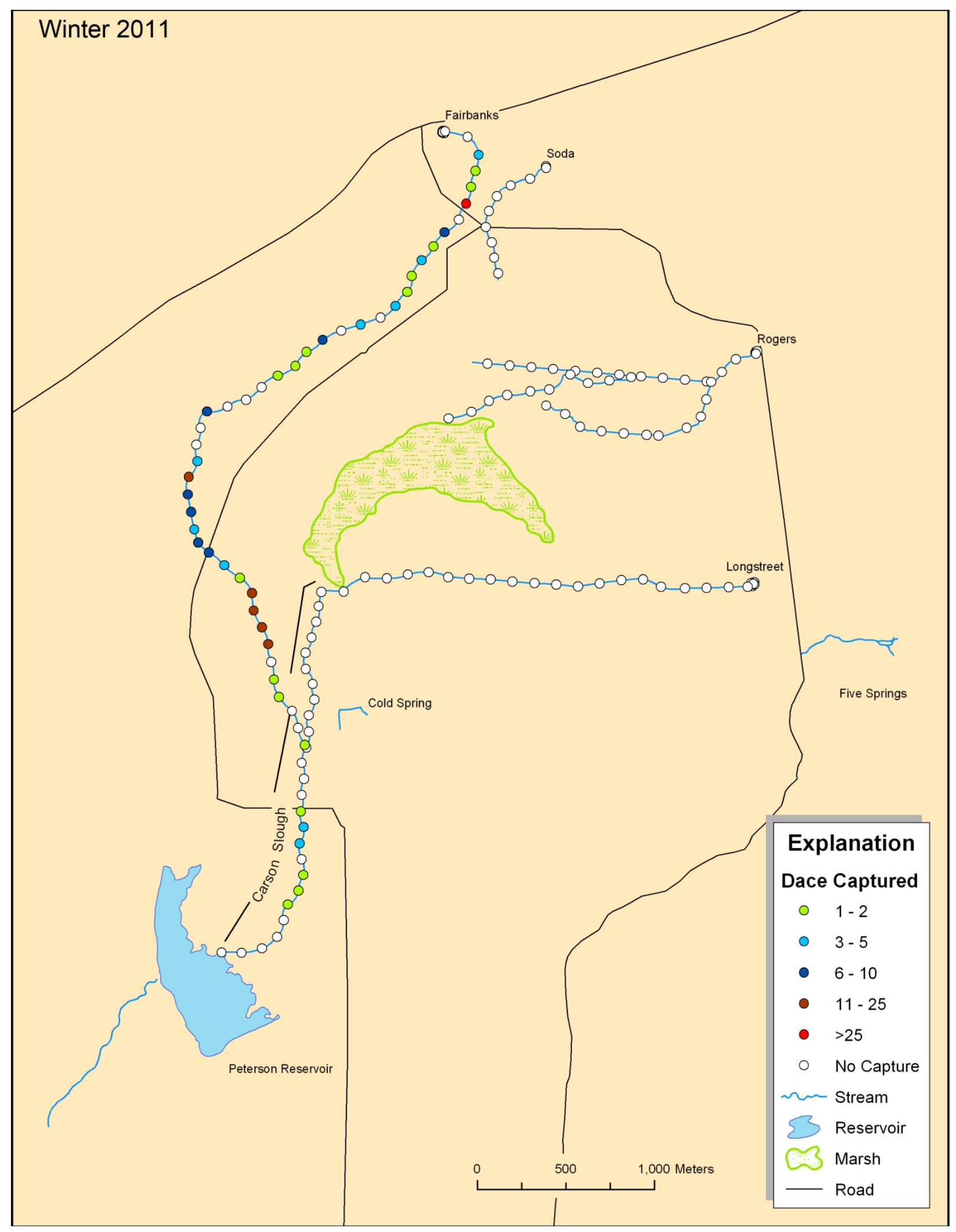

Figure 6. Relative abundance and distribution of Ash Meadows speckled dace in Fairbanks, Soda, Rogers, and Longstreet Springs Ash Meadows National Wildlife Refuge, Nevada, winter 2011. 


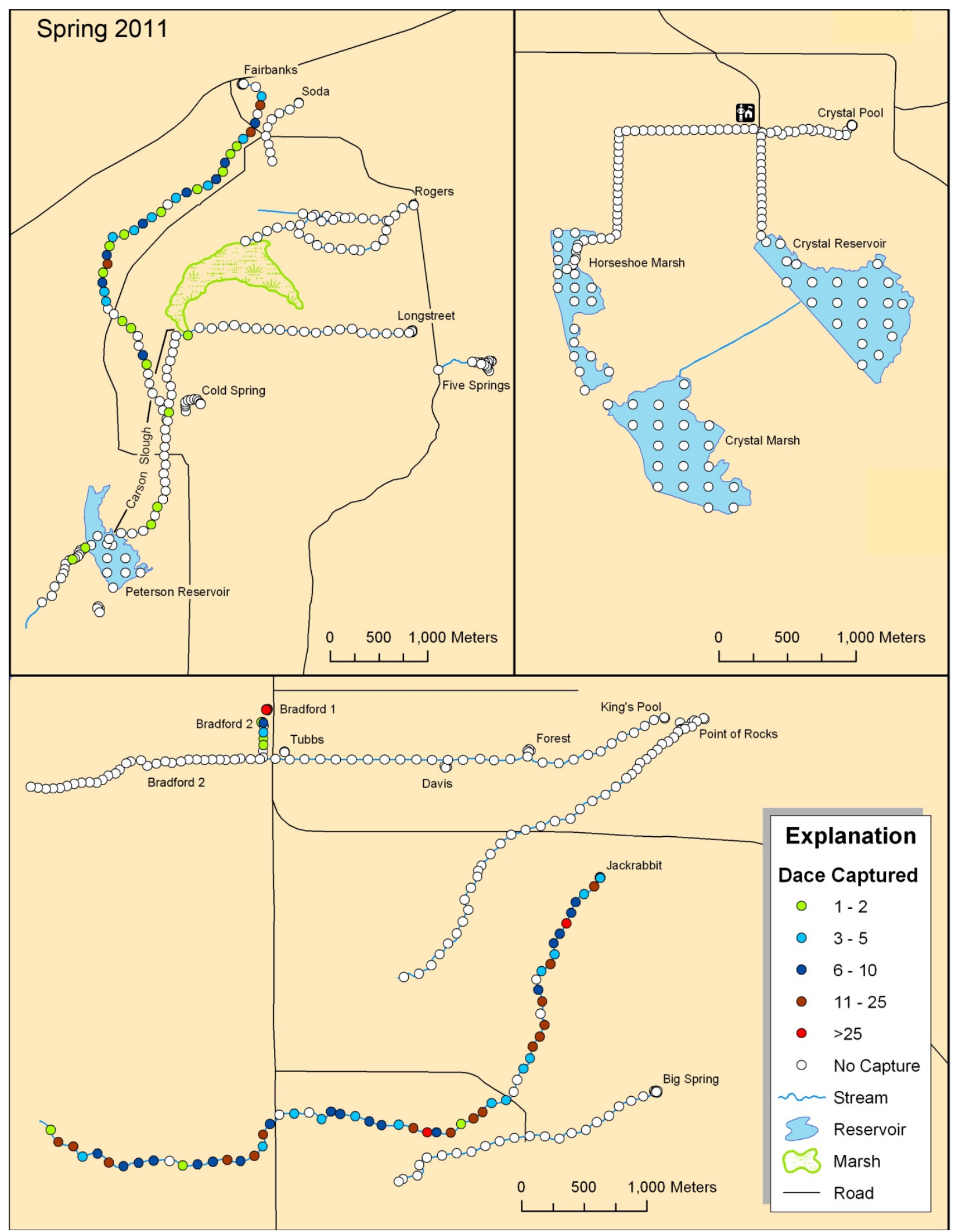

Figure 7. Relative abundance and distribution of Ash Meadows speckled dace throughout Ash Meadows National Wildlife Refuge, Nevada, spring 2011. 


\section{Warm Springs Complex}

Pupfish captures for both North Scruggs and South Scruggs Springs were highest in the fall (95 and 120, respectively; table 2) when juvenile pupfish were abundant in their respective marshes at the downstream end of each of the two springs. In North Scruggs Spring, no pupfish were captured in the upper-most $50 \mathrm{~m}$ of stream in fall or spring; they were distributed over a wider area in the fall (fig. 8). South Scruggs Spring was the only spring-system in the Warm Springs Complex harboring mosquitofish and crayfish (table 2). Mosquitofish were captured within a $400 \mathrm{~m}$ stream reach in fall and $300 \mathrm{~m}$ stream reach in spring (fig. A10). Crayfish were more widespread than pupfish or mosquitofish (fig. A11), and in the fall, there were more crayfish captures than pupfish or mosquitofish captures (table 2).

School and Marsh Springs are truncated systems with more constant water temperatures and pupfish captures were highest in the spring (329 and 123, respectively; table 2). Pupfish was the only species captured from both Marsh and School Springs. The majority of pupfish captures were from the spring outflows (rather than spring-pools) for both systems (table 2). School Spring has undergone extensive restoration since our 2007-08 surveys (Weissenfluh, 2010), and fish were captured throughout the system and not just limited to the spring-pool (fig. 8).

Table 2. Seasonal catches of fishes, bullfrogs, and crayfish in the Warm Springs Complex of the Ash Meadows National Wildlife Refuge, Nevada, fall 2010 and spring 2011.

[Spring locations are shown in figure 1. Species: CYMI, Ash Meadows Amargosa pupfish; CYPE, Warm Springs Amargosa pupfish; GAAF, Mosquitofish; LECY, Green Sunfish; MISA, Largemouth Bass; POLA, Sailfin Molly; PRCL, Red Swamp Crayfish; RACA, Bullfrog; RHON, Ash Meadows speckled dace]

\begin{tabular}{|c|c|c|c|c|c|c|c|c|c|c|}
\hline \multirow{2}{*}{ System } & \multirow{2}{*}{ Season } & \multicolumn{9}{|c|}{ Species } \\
\hline & & CYMI & CYPE & RHON & GAAF & POLA & LECY & MISA & RACA & PRCL \\
\hline \multirow{2}{*}{$\begin{array}{c}\text { North Scruggs } \\
\text { spring-pool }\end{array}$} & Fall 2010 & - & - & - & - & - & - & - & - & - \\
\hline & Spring 2011 & - & - & - & - & - & - & - & - & - \\
\hline \multirow{2}{*}{$\begin{array}{l}\text { North Scruggs } \\
\text { stream }\end{array}$} & Fall 2010 & - & 95 & - & - & - & - & - & - & - \\
\hline & Spring 2011 & - & 58 & - & - & - & - & - & - & - \\
\hline \multirow{2}{*}{$\begin{array}{c}\text { South Scruggs } \\
\text { spring-pool }\end{array}$} & Fall 2010 & - & 1 & - & - & - & - & - & - & 2 \\
\hline & Spring 2011 & - & - & - & - & - & - & - & - & 2 \\
\hline \multirow{2}{*}{$\begin{array}{c}\text { South Scruggs } \\
\text { stream }\end{array}$} & Fall 2010 & - & 120 & - & 13 & - & - & - & - & 131 \\
\hline & Spring 2011 & - & 93 & - & 19 & - & - & - & - & 69 \\
\hline \multirow{2}{*}{$\begin{array}{c}\text { Marsh spring- } \\
\text { pool }\end{array}$} & Fall 2010 & - & - & - & - & - & - & - & - & - \\
\hline & Spring 2011 & - & - & - & - & - & - & - & - & - \\
\hline \multirow{2}{*}{ Marsh Stream } & Fall 2010 & - & 64 & - & - & - & - & - & - & - \\
\hline & Spring 2011 & - & 123 & - & - & - & - & - & - & - \\
\hline $\begin{array}{l}\text { North and South } \\
\text { Indian spring- } \\
\text { pools and } \\
\text { streams }\end{array}$ & \multicolumn{10}{|c|}{ Not surveyed due to ongoing restoration } \\
\hline \multirow{2}{*}{$\begin{array}{c}\text { School spring- } \\
\text { pool }\end{array}$} & Fall 2010 & - & 13 & - & - & - & - & - & - & - \\
\hline & Spring 2011 & - & 2 & - & - & - & - & - & - & - \\
\hline \multirow{2}{*}{ School stream } & Fall 2010 & - & 252 & - & - & - & - & - & - & - \\
\hline & Spring 2011 & - & 329 & - & - & - & - & - & - & - \\
\hline
\end{tabular}




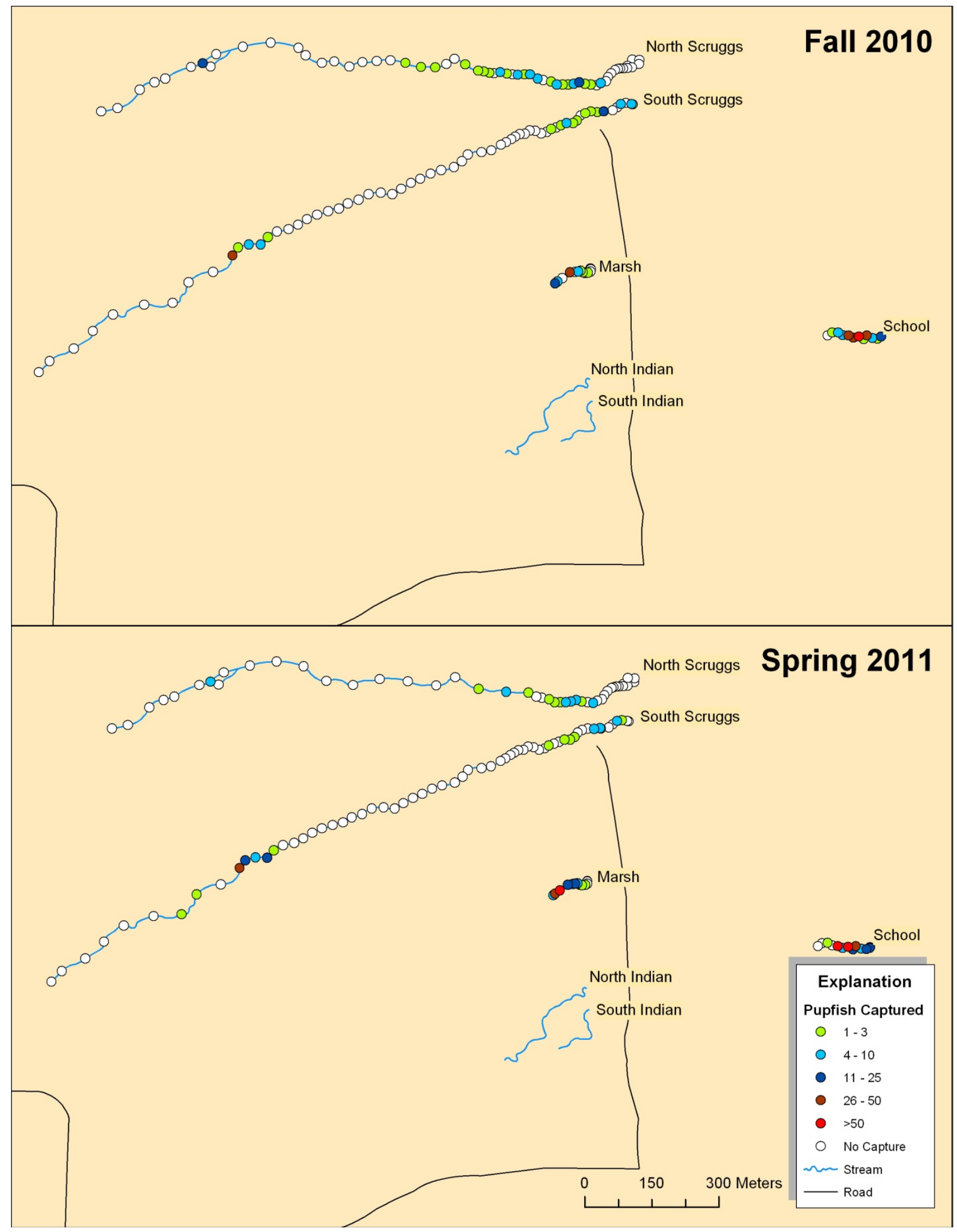

Figure 8. Relative abundance and distribution of pupfish in North Scruggs, South Scruggs, Marsh, and School Springs, Ash Meadows National Wildlife Refuge, Nevada, fall 2010 and spring 2011. 


\section{Southern Springs}

Distribution of pupfish was broader in the Crystal Spring system in spring 2011 than in fall 2010; however, captures in the spring-pool were much greater in the fall than in the spring (table 3, fig. 2). Mosquitofish (figs. A4 and A6) and crayfish (figs. A7 and A9) also were captured in greater numbers and over a broader area in spring 2011. Sailfin molly (figs. A1 and A3) were captured less frequently and at substantially fewer stations than other species, but had slightly greater capture and broader distribution in spring 2011.

Pupfish captures from the spring-pool in Kings Pool Spring were similar in fall 2010 ( $n=647)$ and spring 2011 ( $n=635)$ (table 3). Captures in the outflow stream were substantially less than the spring-pool, and there was a greater disparity in captures between fall 2010 ( $n=137)$ and spring 2011 ( $n=78)$. Most stream captures were upstream of Forest Spring (fig. 2). The mean size of pupfish captured in the stream (34 mm) was greater than pupfish captured from the spring-pool (32 mm) (table A3).

The greatest capture of pupfish in the Point of Rocks Springs system was in spring 2011 with the greatest density in the upper and lower end of the system. Only three speckled dace were captured and this was during the fall sampling period. Few mollies were captured and these were relegated to the upper reaches (figs. A1 and A3). Mosquitofish were abundant with the highest captures and greatest distribution in fall 2010 (table 3; figs. A4 and A6). Crayfish also were abundant and widespread in the fall 2010 and spring 2011, but crayfish had a wider distribution in spring 2011 (figs. A7 and A9). Crayfish captures tended to be highest in the upper springbrook but below the spring-pool in an area where pupfish captures tended to be less (figs. 2-3; figs. A7 and A9).

The only fishes captured from Bradford 1 Spring were speckled dace and mosquitofish. Bradford 1 Spring supported a substantial number of speckled dace for its limited habitat, but many were juveniles (<50 mm FL; table A3). Four aquatic species were captured in Bradford 2 Spring (pupfish, speckled dace, mosquitofish, and crayfish), but only mosquitofish were captured with great frequency (table 3). More mosquitofish were captured than crayfish, but crayfish were captured at more sampling sites, occurring throughout the springbrook downstream of the source pools (figs. A4, A6, A7, and A9). Mosquitofish also was the predominant species captured in Forest Spring, followed by crayfish. One speckled dace in fall 2010 was the only fish captured in Tubbs Spring, which is heavily infested with crayfish. Only crayfish were captured from Davis Spring.

The greatest number of pupfish captured in Big Spring was in spring 2011 for the springpool and outflow stream (table 3, fig. 2). Mosquitofish was the most frequently captured nonnative fish, and capture success and distribution was greatest in fall 2010. Mollies were sparse in both fall 2010 and spring 2011 (fig. A3). The greatest number of crayfish was captured in the spring-pool and stream in spring 2011, but broadest distribution was in fall 2010 (fig. A11).

The greatest capture of pupfish in the Jackrabbit Spring system was in the spring-pool, and the greatest capture for speckled dace was in the stream. Pupfish and speckled dace captures were highest in fall 2010 (table 3, fig. 2). Both species had their broadest distribution in fall 2010. Along with their greater number in the stream, speckled dace had broader distribution than pupfish, and in fall 2010, speckled dace was captured in all but two sample locations. Mosquitofish and crayfish were abundant and widespread throughout the system, with the greatest capture and distribution in fall 2010. Mollies were limited in both distribution and number with the greatest number captured in spring 2011 in the spring-pool. 
Table 3. Seasonal catches of fishes, bullfrogs, and crayfish at the Southern Springs of the Ash Meadows National Wildlife Refuge, Nevada, fall 2010 and spring 2011.

[No sampling of these springs in winter 2011. Spring locations are shown in figure 1. Species: CYMI, Ash Meadows Amargosa pupfish; CYPE, Warm Springs Amargosa pupfish; GAAF, Mosquitofish; LECY, Green Sunfish; MISA, Largemouth Bass; POLA, Sailfin Molly; PRCL, Red Swamp Crayfish; RACA, Bullfrog; RHON, Ash Meadows speckled dace]

\begin{tabular}{|c|c|c|c|c|c|c|c|c|c|c|}
\hline \multirow{2}{*}{ System } & \multirow{2}{*}{ Season } & \multicolumn{9}{|c|}{ Species } \\
\hline & & CYMI & CYPE & RHON & GAAF & POLA & LECY & MISA & RACA & PRCL \\
\hline \multirow{2}{*}{ Crystal spring-pool } & Fall 2010 & 455 & - & - & 217 & - & - & - & - & 29 \\
\hline & Spring 2011 & 78 & - & - & 16 & - & - & - & - & - \\
\hline \multirow{2}{*}{ Crystal stream } & Fall 2010 & 619 & - & - & 364 & 68 & - & - & - & 561 \\
\hline & Spring 2011 & 1,499 & - & - & 404 & 100 & - & - & - & 273 \\
\hline \multirow{2}{*}{ Crystal reservoir } & Fall 2010 & - & - & - & - & - & 37 & - & - & - \\
\hline & Spring 2011 & - & - & - & - & - & 1 & 3 & - & - \\
\hline \multirow{2}{*}{ Crystal marsh } & Fall 2010 & 13 & - & - & 1 & - & 52 & - & - & - \\
\hline & Spring 2011 & 1 & - & - & 22 & - & 39 & - & - & - \\
\hline \multirow{2}{*}{ Horseshoe marsh } & Fall 2010 & 11 & - & - & 35 & 14 & 1 & 1 & - & 86 \\
\hline & Spring 2011 & 9 & - & - & 83 & - & 1 & - & - & 100 \\
\hline \multirow{2}{*}{$\begin{array}{c}\begin{array}{c}\text { Kings Pool spring- } \\
\text { pool }\end{array} \\
\end{array}$} & Fall 2010 & 647 & - & - & 6 & 10 & - & - & - & - \\
\hline & Spring 2011 & 635 & - & - & 21 & - & - & - & - & - \\
\hline \multirow{2}{*}{ Kings Pool stream } & Fall 2010 & 137 & - & - & 123 & 19 & - & - & - & 59 \\
\hline & Spring 2011 & 78 & - & - & 33 & 20 & - & - & - & 60 \\
\hline \multirow{2}{*}{ Point of Rocks stream } & Fall 2010 & 252 & - & 3 & 85 & 9 & - & - & - & 113 \\
\hline & Spring 2011 & 368 & - & - & 62 & 11 & - & - & - & 123 \\
\hline \multirow{2}{*}{$\begin{array}{l}\text { Bradford } 1 \text { spring- } \\
\text { pool }\end{array}$} & Fall 2010 & - & - & 145 & 9 & - & - & - & - & 58 \\
\hline & Spring 2011 & - & - & 161 & 16 & - & - & - & - & 32 \\
\hline Bradford 1 stream & \multicolumn{10}{|c|}{ There is no longer an outflow channel due to restoration } \\
\hline \multirow{2}{*}{$\begin{array}{c}\text { Bradford } 2 \text { spring- } \\
\text { pool }\end{array}$} & Fall 2010 & - & - & - & 466 & - & - & - & 1 & 20 \\
\hline & Spring 2011 & - & - & 5 & 294 & - & - & - & - & 54 \\
\hline \multirow{2}{*}{ Bradford 2 stream } & Fall 2010 & 12 & - & 16 & 174 & 15 & - & - & - & 131 \\
\hline & Spring 2011 & 34 & - & 13 & 177 & 10 & - & - & - & 89 \\
\hline \multirow{2}{*}{ Forest spring-pool } & Fall 2010 & 9 & - & - & 235 & 7 & - & - & - & 75 \\
\hline & Spring 2011 & 3 & - & - & 53 & - & - & - & - & 40 \\
\hline \multirow{2}{*}{ Tubbs spring-pool } & Fall 2010 & - & - & 1 & - & - & - & - & - & 67 \\
\hline & Spring 2011 & - & - & - & - & - & - & - & - & 28 \\
\hline \multirow{2}{*}{ Davis spring-pool } & Fall 2010 & - & - & - & - & - & - & - & - & 11 \\
\hline & Spring 2011 & - & - & - & - & - & - & - & - & - \\
\hline \multirow{2}{*}{$\begin{array}{l}\begin{array}{l}\text { Jackrabbit spring- } \\
\text { pool }\end{array} \\
\end{array}$} & Fall 2010 & 474 & - & 3 & 42 & 3 & - & - & - & 14 \\
\hline & Spring 2011 & 468 & - & 10 & 22 & 54 & - & - & - & 11 \\
\hline \multirow{2}{*}{ Jackrabbit stream } & Fall 2010 & 118 & - & 623 & 224 & 4 & - & - & - & 261 \\
\hline & Spring 2011 & 68 & - & 538 & 28 & 6 & - & - & - & 123 \\
\hline \multirow{2}{*}{$\begin{array}{c}\text { Big Spring spring- } \\
\text { pool }\end{array}$} & Fall 2010 & 221 & - & - & 106 & 21 & - & - & - & 23 \\
\hline & Spring 2011 & 310 & - & - & 26 & 13 & - & - & - & 35 \\
\hline \multirow{2}{*}{ Big Spring stream } & Fall 2010 & 54 & - & - & 195 & 18 & - & - & 1 & 94 \\
\hline & Spring 2011 & 201 & - & - & 85 & 11 & - & - & 1 & 131 \\
\hline
\end{tabular}




\section{Discussion}

Results of this study illustrate the status of native fish species better than the status of non-native fish species. Mosquitofish are surface dwellers (Scoppettone, 1993), and presumably do not typically encounter minnow traps lying on the stream bottom. Pupfish and speckled dace are more benthically oriented (Scoppettone and others, 2005) and consequently are more like to encounter traps. Sailfin molly demonstrate greater trap avoidance than mosquitofish, pupfish, or speckled dace, and thus our trapping data likely underestimated the abundance of sailfin molly, although its distribution is accurately portrayed.

There was no consistent seasonal trend in capture success among species—several factors likely contributed to this condition. Population numbers in Crystal and Big Springs were probably influenced by invasive predators (largemouth bass in Big Spring and green sunfish (Lepomis cyanellus) and perhaps largemouth bass in Crystal Spring). These predators probably impacted both spring systems during or between surveys. AMNWR staff removed 46 green sunfish from these systems since October 5, 2010, with none having been caught after 2 were removed on June 21, 2011 (Darrick Weissenfluh, Ash Meadows National Wildlife Refuge, oral commun., 2011). Fish population numbers at the Jackrabbit Spring system are being influenced by the spread of coyote willow. Predictably, the effect on pupfish is negative because pupfish feed on algae, which in turn requires sunlight (Kennedy and others, 2006). The effect on speckled dace needs further evaluation. Restoration efforts at Fairbanks and Soda Springs occurred during the survey, and profoundly influenced numbers and distribution of fishes and crayfish. Restoration of Fairbanks' and Soda springs' channels altered their previous connectivity relationships with the Longstreet, Rogers, and Cold Springs systems, thus influencing abundance and distribution of fishes in those systems as well.

\section{Northern Springs}

The abundance and widespread distribution of Ash Meadows Amargosa pupfish in the newly restored Fairbanks and Soda Springs demonstrate that open-water habitat is conducive to this species (Kennedy and others, 2006; Scoppettone and others, 2011a). The future relative abundance and distribution of pupfish probably will be influenced by how open the channel remains to sunlight. Thus where pupfish are concerned, it is important to encourage open-water habitats whenever possible, which is important for restoration considerations, including revegetation options.

The shift in the Soda Spring fish community is particularly noteworthy. Only mosquitofish were captured in the 2007-08 survey, with no pupfish recorded. During this survey, hundreds of pupfish were captured and 21 speckled dace from Jackrabbit Spring were introduced into the system in March 2011. Although none were captured during the spring 2011 sampling period, AMNWR personnel captured nine in July 2011 (Darrick Weissenfluh, Ash Meadows National Wildlife Refuge, oral commun., 2011). Speckled dace occupy a wide range of habitat types (Moyle, 2002), including low-discharge spring systems, such as Soda Spring. However, there are frequent impacts from invasive crayfish and mosquitofish in shallow low-discharge systems. Soda Spring presents an opportunity to test whether speckled dace can persist in a low volume spring system in the presence of these invasive species. 
Repatriation of speckled dace to the Fairbanks Spring system appears to have succeeded. More dace were captured in the minnow traps during each of the three seasons sampled than the 118 dace introduced to the system. Reintroduction of speckled dace occurred within several months of phase 1 post-restoration, when mosquitofish and crayfish numbers were low. A relatively low number of these predatory invasive species probably enhanced survival of speckled dace eggs and larvae (Leavy and others, 2004). Restoration of Longstreet and Rogers Springs is anticipated to allow speckled dace expansion in the Northern Springs area.

No sailfin molly was captured from the Longstreet Spring system during the spring 2011 sampling, suggesting that the February 2011 treatment was successful. The species appears to no longer be a threat to spread in the Northern Springs area.

\section{Warm Springs Complex}

Warm Springs pupfish have endured substantial habitat alteration and past invasion by non-native species (Miller and Deacon, 1973). When Scruggs Springs was discovered to harbor pupfish in 1967, both springs were already highly altered and non-native mosquitofish had invaded as well. Miller and Deacon (1973) showed Indian Spring as just one spring discharging into a reservoir; it too harbored pupfish and mosquitofish. When Scoppettone and others (1995) sampled the Warm Springs Complex, only Indian Spring was inhabited by mosquitofish and crayfish. By 2001, mosquitofish and crayfish also were reported from South Scruggs and School Springs, and the number of Warm Spring pupfish appeared to be decreasing (St. George, 2001).

There was a marked difference between the number of pupfish captured in North Scruggs by Scoppettone and others (2011b) in spring $2008(n=81)$ and in this study $(n=58)$, even though more stations were sampled in this study due to acquisition of a private land. Reasons for the substantial difference are unknown; however, the property acquisition presents an opportunity to improve habitat with the intent of expanding the range and number of pupfish. South Scruggs Spring harbored both mosquitofish and crayfish during both surveys; there was a greater number of pupfish captured in South Scruggs Spring than in North Scruggs Spring in fall 2010. Most of these were juveniles captured in shallow marsh habitat near the outflow terminus. South Scruggs Spring also had substantially greater flow than North Scruggs Spring. Once non-native mosquitofish and crayfish are eradicated from the South Scruggs Spring system, the Warm Springs pupfish population is expected to increase even more.

The outflow of Marsh Spring had changed between this survey and the 2007-08 survey. The terminal marsh was more thickly vegetated resulting in less open water. Total number of pupfish captured was only 64 in fall 2010 and 123 in spring 2011. The greatest pupfish capture success was in School Spring with 252 in fall 2010 and 329 in spring 2011. Capture success was highest in spring 2011 for both Marsh and School Springs, but was highest in fall 2010 for North and South Scruggs Springs. We attribute this difference to the annual proliferation of pupfish that occurs in the shallow marshes of the North and South Scruggs Spring system. Populations in marshes begin to proliferate in spring and reach their maximum number by fall. Many of the pupfish captured from the shallow marsh are juveniles (table A2) that apparently do not survive the winter. Presumably because of their more stable temperature, School and Marsh Springs do not support the relatively "boom and bust" populations seen at the North and South Scruggs Spring system. 


\section{Southern Springs}

Since AMNWR was established, the Southern Springs have been plagued with largemouth bass and green sunfish invasions at various times (Threloff, 1990b; St. George, 1995, 1998, 1999, 2001; Ambruzs and others, 2006). Crystal Reservoir harbored largemouth bass when AMNWR was acquired and they have intermittently invaded Crystal spring-pool and the outflow stream; these invasions are followed by decreases in the pupfish population. Since the 2007-08 survey, green sunfish also invaded Crystal Spring outflow and were present in the system during our fall 2010 and spring 2011 sampling period (Darrick Weissenfluh, Ash Meadows National Wildlife Refuge, oral commun., 2011). Amargosa pupfish typically are in greatest numbers in open-water habitat with ample algae production, and in fewer numbers in heavily shaded habitat (Kennedy and others, 2006; Scoppettone and others, 2011a). The canopy over Kings Pool stream has increased since the outflow was restored in 1997 and we suspect pupfish numbers have declined, but we have no direct comparisons. The number of pupfish captured in fall 2010 and spring 2011 were somewhat less than the number captured in the 2007-08 survey, but so were invasive mosquitofish and crayfish — species reported to increase with canopy cover. Pupfish captures in Jackrabbit stream also were less than the 2007-08 survey and this may be due to increased riparian growth and resulting cover, although again the captures of invasive mosquitofish and crayfish also were less.

AMNWR staff captured two speckled dace at Tubbs Spring in October 2006 and another in July 2007 (Darrick Weissenfluh, Ash Meadows National Wildlife Refuge, oral commun., 2011). One speckled dace was captured in Tubbs Spring in fall 2010. These captures are the first dace captures at this spring since 1996 (St. George, 1997). The spring was chemically treated in 1998 (Jon Sjöberg, Nevada Department of Wildlife, written commun., 2011) resulting in the eradication of mosquitofish and sailfin molly. No fish were captured from Tubbs Spring in the 2007-08 survey. A pipe runs from Tubbs Spring to the Kings Pool outflow (Threloff, 1990a), and we suspect that the dace accessed Tubbs Spring through the pipe. Speckled dace was reintroduced into Forest Spring and Point of Rocks Spring in 2003. We suspect that crayfish, mosquitofish, and sailfin molly have prevented the introduced fish from establishing strong reproductive populations. Only three dace were captured in Point of Rocks Spring in fall 2010 and none in spring 2011. There were no speckled dace captures from Forest Spring although AMNWR staff did capture one in October 2006 and two in August 2007 (Darrick Weissenfluh, Ash Meadows National Wildlife Refuge, oral commun., 2011). When crayfish and mosquitofish were aggressively and systematically removed from Bradford 1 and 2 Springs, the speckled dace population responded with a substantial increase. Bradford 1 Spring supported a fairly robust population of speckled dace for its restricted area, but most captured dace were juveniles and few reached adulthood (>50 mm FL) (G.G. Scoppettone, U.S. Geological Survey, personal observation, 2011 ). This suggests that Bradford 1 habitat is capable of supporting relatively few adult dace. The stronghold for speckled dace in the Southern Springs area is the Jackrabbit Spring system, although Bradford 1 and 2 Springs support reproductive populations as well. 


\section{Conclusions}

1. Restoration of Fairbanks Spring has led to an increase in the Ash Meadows pupfish population, and speckled dace were successfully repatriated into the Northern Springs.

2. Post-restoration of Fairbanks Spring, mosquitofish and crayfish were relatively few in number and limited in distribution.

3. Capture of Ash Meadows pupfish in Soda Spring changed from no captures in the 200708 survey (pre-restoration) to hundreds in this study (post-restoration), with most fish occupying the shallow open marsh near the spring discharge terminus.

4. Sailfin molly appeared to have been successfully eradicated from the Longstreet Spring system — none were captured during our spring 2011 sampling soon after the spring system was chemically treated. Mosquitofish were not eradicated from the system.

5. Although connected by marsh habitat with Longstreet Spring, Rogers Spring did not harbor sailfin molly.

6. Cold Spring was the only Northern Spring system without mosquitofish captures. Ash Meadows pupfish were rare but invasive crayfish were common at this site.

7. Eradication of mosquitofish and red swamp crayfish from South Scruggs Spring, the only spring in the Warm Springs Complex harboring them, would lead to an increase in pupfish and decrease in the risk of spread of these invasive species. This would be a valuable management prescription for this site.

8. Restoration of North Scruggs and Marsh Springs may lead to increase in resident pupfish populations.

9. Pupfish were found concentrated in North and South Scruggs spring systems in the upper reaches where water temperatures remain constantly warm, and near downstream most perennial water where the water is shallow and subject to ample sunlight.

10. Marsh and School Springs had relatively short outflow stream prior to discharging into a marsh, and most pupfish in these systems appear to be subject to fairly constant thermal environs.

11. Invasive centrarchids in Crystal and Big Springs were suspected to have a negative influence on pupfish numbers during this study, making comparisons of Ash Meadows pupfish population among seasons and years difficult.

12. Bradford 1 Spring supported a fairly sizable speckled dace population, but only few are expected to reach adulthood. Bradford 2 Spring continues to support a reproductive population of speckled dace, although the population does not appear to be robust.

13. One speckled dace was captured from Tubbs Spring. This fish was suspected to have entered Tubbs Spring through a pipe that extends to Kings Pool outflow.

14. Davis Spring remained fishless, but crayfish are still present.

15. Native fish populations are down in Jackrabbit Spring, and expansion of coyote willow along the banks of this spring is the suspected cause. Jackrabbit Spring remains the stronghold for Ash Meadows speckled dace. 
17. The Point of Rock spring system is another low water volume spring system with pupfish concentrated near the thermal discharge, and near the stream terminus where the water was shallow and subject to ample sunlight. Water temperature fluctuates dramatically throughout the year. As with the North and South Scruggs Spring systems, the middle reaches are heavily vegetated and receive little sunlight.

18. Speckled dace introduced into Point of Rocks and Forest Springs did not appear to be successful. None were captured from Forest Spring and only three from Point of Rocks Spring during the fall 2010 survey.

19. The pupfish population in Kings Pool Spring spring-pool remains fairly robust, but numbers in the stream outflow are down substantially from the 2007-08 survey, presumably due to greater shading of the stream channel.

\section{Acknowledgments}

We thank Ash Meadows National Wildlife Refuge for funding the project and assisting with lodging. Thanks also to Kevin Guadalupe and Jeff Goldstein (Great Basin Institute) for field assistance.

\section{References Cited}

Ambruzs, S., Salgado, J.A., Scoppettone, G.G., and Goodchild, S., 2006, Survey of Ash Meadows speckled dace and pupfish in Jackrabbit Spring: U.S. Geological Survey Biological Resources Discipline, Reno Field Station and U.S. Fish and Wildlife Service, Southern Nevada Field Office, 8 p.

Baugh, T., Williams, J.E., Buck, D.A., and Deacon, J.E., 1986, New distributional records for Cyprinodon nevadensis mionectes, an endangered pupfish from Ash Meadows, Nevada: The Southwestern Naturalist, v. 31, p. 544-546.

Deacon, J.E., Hubbs, C., and Zahuranec, B.J., 1964, Some effects of introduced fishes on the native fish fauna of southern Nevada: Copeia, p. 384-388.

Deacon, J.E., and Williams, C.D., 1991, Ash Meadows and the legacy of the Devils Hole pupfish, in Minckley, W.L., and Deacon, J.E. (eds.), Battle against extinction-Native fish management in the American West: Tucson, The University of Arizona Press, p. 69-87.

Dudley, W.W., Jr., and Larson, J.D., 1976, Effect of irrigation pumping on desert pupfish habitats in Ash Meadows, Nye County, Nevada: U.S. Geological Survey Professional Paper 927, 153 p.

Freeman, M.A., Turnbull, J.F., Yeomans, W.E., and Bean, C.W., 2010, Prospects for management strategies of invasive crayfish populations with an emphasis on biological control: Aquatic Conservation: Marine and Freshwater Ecosystems, v. 20, p. 211-233.

Hershler, R., and Sada, D.W., 1987, Springsnails (Gastropoda:Hydrobiidae) of Ash Meadows, Amargosa Basin, California-Nevada: Proceedings of the Biological Society of Washington, v. 100, p. 776-843.

Kennedy, T.A., Finlay, J.C., and Hobbie, S.E., 2006, Eradication of invasive Tamarix ramosissima along a desert stream increase native fish density: Ecological Applications, v. 15, p. 2072-2083. 
Knight, T.A., and Clemmer, G.H., 1987, Status of populations of the endemic plants of Ash Meadows, Nye County, Nevada: a report to U.S. Fish and Wildlife Service, Great Basin Complex, Reno Nevada, Project Agreement No. 86-2-1., Nevada Division of Forestry Department of Conservation and Natural Resources and Nevada Natural Heritage Program, Carson City, Nev.

Landye, J.J., 1973, Status of the inland aquatic and semi-aquatic mollusks of the American Southwest: Lower Colorado River Basin Research Laboratory, 60 p.

Leavy, T.R., McShane, R.R., Swaim, K.M., and Scoppettone G.G., 2004, (Part II) Status of Ash Meadows speckled dace in Bradford Springs, in Information on native fishes and invasive fishes and crayfish at Ash Meadows National Wildlife Refuge: U.S. Geological Survey, Biological Resources Division, Western Fisheries Research Center, Reno Field Station, p. 111.

McShane, R.R., Swaim, K.M., and Scoppettone, G.G., 2004, (Part I) Implication of habitat restoration for managing exotic crayfish at Ash Meadows, in Information on native fishes and invasive fishes and crayfish at Ash Meadows National Wildlife Refuge: U.S. Geological Survey, Biological Resources Division, Western Fisheries Research Center, Reno Field Station, p. 1-26.

Meffe, G.K., 1983, Attempted chemical renovation of an Arizona spring-brook for management of the endangered Sonoran topminnow: North American Journal of Fisheries Management, v. 3, p. 315-321.

Meronek, T.G., Bouchard, P.M., Buckner, E.R., Burri, T.M., Demmerly, K.K., Hatheli, D.C., Klumb, R.A., Schmidt, S.H., and Coble, D.W., 1996, A review of fish control projects: North American Journal of Fisheries Management, v. 16, p. 63-74.

Miller, R.R., 1948, The cyprinodont fishes of the Death Valley System of eastern California and Southwestern Nevada: Miscellaneous Publications Museum of Zoology, University of Michigan, v. 68, 155 p.

Miller, R.R., 1961, Man and the changing fauna of the American Southwest: Papers of the Michigan Academy of Science, Arts, and Letters, v. 46, p. 365-404.

Miller, R.R. and Deacon, J.E., 1973, New localities of the rare Warm Spring pupfish, Cyprinodon nevadensis pectoralis, from Ash Meadows: Copeia, p. 137-140.

Miller, R.R., Williams, J.D., and Williams, J.E., 1989, Extinction of North American fishes during the past century, Fisheries (Bethesda), v. 14, p. 22-38.

Minckley, W.L., and Deacon, J.E., 1991, Battle against extinction: native fish management in the American West: Tucson, The University of Arizona Press.

Mitchell, A.J., Hobbs, M.S., and Brandt, T.M., 2007, The effect of chemical treatment on redrim melania Melanoides tuberculata, and exotic aquatic snail that serves as a vector of trematodes to fish and other species in the USA: North American Journal of Fisheries Management, v. 27, p. 1287-1293.

Moyle, P.B., 2002, Inland fishes of California: Berkeley, University of California Press.

Moyle, P.B., Li, H.W., and Barton, B.A., 1986, The Frankenstein effect: impact of introduced fishes on native fishes in North America, in Stround, R.H. (ed.), Fish culture in fisheries management: American Fisheries Society, Fish Culture Section and Fisheries Management Section, Bethesda, Maryland, p. 415-426.

Olden, J.D., and Poff, N.L., 2005, Long-term trends of native and non-native fish faunas in the American Southwest: Animal Biodiversity and Conservation, v. 28, p. 75-89. 
Pister, E.P., 1974, Desert fishes and their habitats: Transactions of the American Fisheries Society, v. 103, p. 531-540.

Pister, E.P., 1985, Desert pupfishes: reflections on reality, desirability, and conscience: Fisheries, v. 10 , p. $10-15$.

Rinne, J.N., and Turner, P.R., 1991, Reclamation and alteration as management techniques, and a review of methodology in stream renovation, in Minckley, W.L., and Deacon, J. E. (eds.), Battle against extinction: native fish management in the American West: Tucson, University of Arizona Press.

Sada, D.W., 1990, Recovery plan for the endangered and threatened species of Ash Meadows, Nevada: Reno, Nev., U.S. Fish and Wildlife Service.

Scoppettone, G.G., 1993, Interactions between native nonnative fishes of the upper Muddy

River, Nevada: Transactions of the American Fisheries Society, v. 122, p. 599-608.

Scoppettone, G.G., Rissler, P.H., Byers, S., Shea, S., Nielsen, B., and Sjöberg, J., 1995, Information on the status and ecology of Ash Meadows Fishes and Ambrysus: National Biological Service, Reno Field Station, 111 p.

Scoppettone, G.G., Hereford, M.E., Rissler, P.H., Johnson, D.M., and Salgado, J.A., 2011a, Relative abundance and distribution of fishes within an established Area of Critical Environmental Concern of the Amargosa River Canyon and Willow Creek, Inyo and San Bernardino Counties, California: U.S. Geological Survey Open-File Report 2011-1161, 32 p. Scoppettone, G.G., Rissler, P., Johnson, D., and Hereford, M., 2011b, Relative abundance and distribution of fishes and crayfish at Ash Meadows National Wildlife Refuge, Nye County, Nevada, 2007-08: U.S. Geological Survey Open-File Report 2011-1017, 56 p.

Scoppettone, G.G., Rissler, P., Gourley, C., and Martinez, C., 2005, Habitat restoration as a means of controlling non-native fish in a Mojave Desert Oasis: Restoration Ecology, v. 13, p. 247-256.

Soltz, K.L., and Naiman, R.J., 1978, The natural history of native fishes in the Death Valley system: Natural History Museum of Los Angeles County, California, Science Series, v. 30, $76 \mathrm{p}$.

St. George, D., 1995, Ash Meadows National Wildlife Refuge annual endangered fish survey Fall 1994: Ash Meadows National Wildlife Refuge, Nevada, 6 p.

St. George, D., 1998, Ash Meadows National Wildlife Refuge 1997 native fish survey: Ash Meadows National Wildlife Refuge, Nevada, 8 p.

St. George, D., 1999, Ash Meadows National Wildlife Refuge nonnative fishes eradication report 1998: Ash Meadows National Wildlife Refuge, Nevada, 4 p.

St. George, D., 2000, Ash Meadows National Wildlife Refuge 1999 native fish survey: Ash Meadows National Wildlife Refuge, 10 p.

St. George, D., 2001, Ash Meadows National Wildlife Refuge 2001 native fish survey: Ash Meadows National Wildlife Refuge, 8 p.

Taylor, D., 1980, Endangered and threatened freshwater mollusks of Amargosa drainage, California-Nevada: Proposal to Office of Endangered Species, U.S. Fish and Wildlife Service-Tiburon Center for Environmental Studies, San Francisco State University.

Taylor, J.N., Courtenay, W.R., Jr., and McCann, J.A., 1984, Known impacts of exotic fishes in the continental United States, in Courtenay, W.R., Jr., and Stauffer, J.R., Jr., (eds.), Distribution, biology, and management of exotic fishes: Baltimore, Maryland, Johns Hopkins University Press. 
Threloff, D., 1990a, The distribution and abundance of the fishes of Ash Meadows: a preliminary inventory: Ash Meadows National Wildlife Refuge, 23 p.

Threloff, D., 1990b, Ash Meadows Biannual Fish Count Summary: Ash Meadow National Wildlife Refuge, $11 \mathrm{p}$.

U.S. Department of the Interior, 1971, Status of desert pupfish, A progress report on the status of the desert pupfish, $14 \mathrm{p}$.

U.S. Fish and Wildlife Service, 1989, 50 CFR part 17, Endangered and threatened wildlife and plants: animal notice of review. Federal Register 54, 554-579.

Weissenfluh, D., 2008a, Ash Meadows NWR aquatic exotic control activities summary accomplish report (FY2008), U.S. Fish and Wildlife Service, 9 p.

Weissenfluh, D., 2008b, Davis Spring Aquatic Nuisance Species Eradication Accomplishment Report, U.S. Fish and Wildlife Service, 5 p.

Weissenfluh, D., 2008c, School Springs Refugium Restoration Accomplishment Report, U. S. Fish and Wildlife Service, 9 p.

Weissenfluh, D., 2010, Conservation of Cyprinodon nevadensis pectoralis and three endemic aquatic invertebrates in an artificial desert spring refuge located in Ash Meadows National Wildlife Refuge, Nevada, M.S. Thesis, Department of Biological Sciences, Texas Tech University, Lubbock, Tex.

Williams, J.E., Bowman, D.B., Brooks, J.E., Echelle, A.A., Edwards, R.J., Hendrickson, D.A., and Landye, J.J., 1985, Endangered aquatic ecosystems in North American deserts with a list of vanishing fishes of the region: Journal of Arizona-Nevada Academy of Sciences, v. 20, $60 \mathrm{p}$.

Williams, J.E., and Sada, D.W., 1985, Status of two endangered fishes, Cyrpinodon nevadensis mionectes and Rhinichthys osculus nevadensis, from two springs in Ash Meadows, Nevada: The Southwestern Naturalist, v. 30, p. 475-484.

Yoakum, J.D., Lockard, D., Osborn, C., Deacon, J., Allan, C., and Kobetich, G., 1976, Warm Springs pupfish recovery plan: U.S. Fish and Wildlife Service. 
This page left intentionally blank 


\section{Appendix A.}

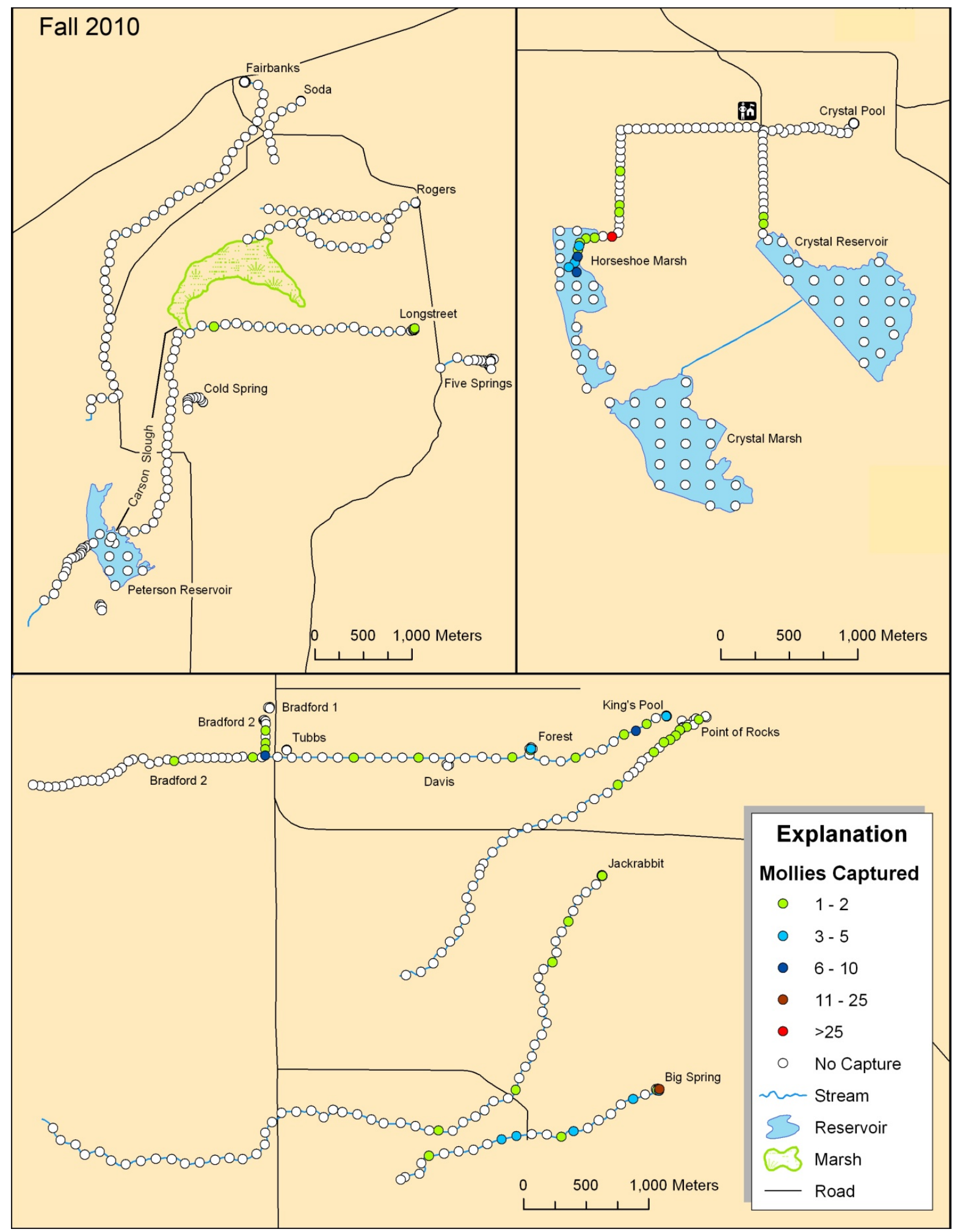

Figure A1. Relative abundance and distribution of sailfin molly throughout Ash Meadows National Wildlife Refuge, Nevada, fall 2010. 


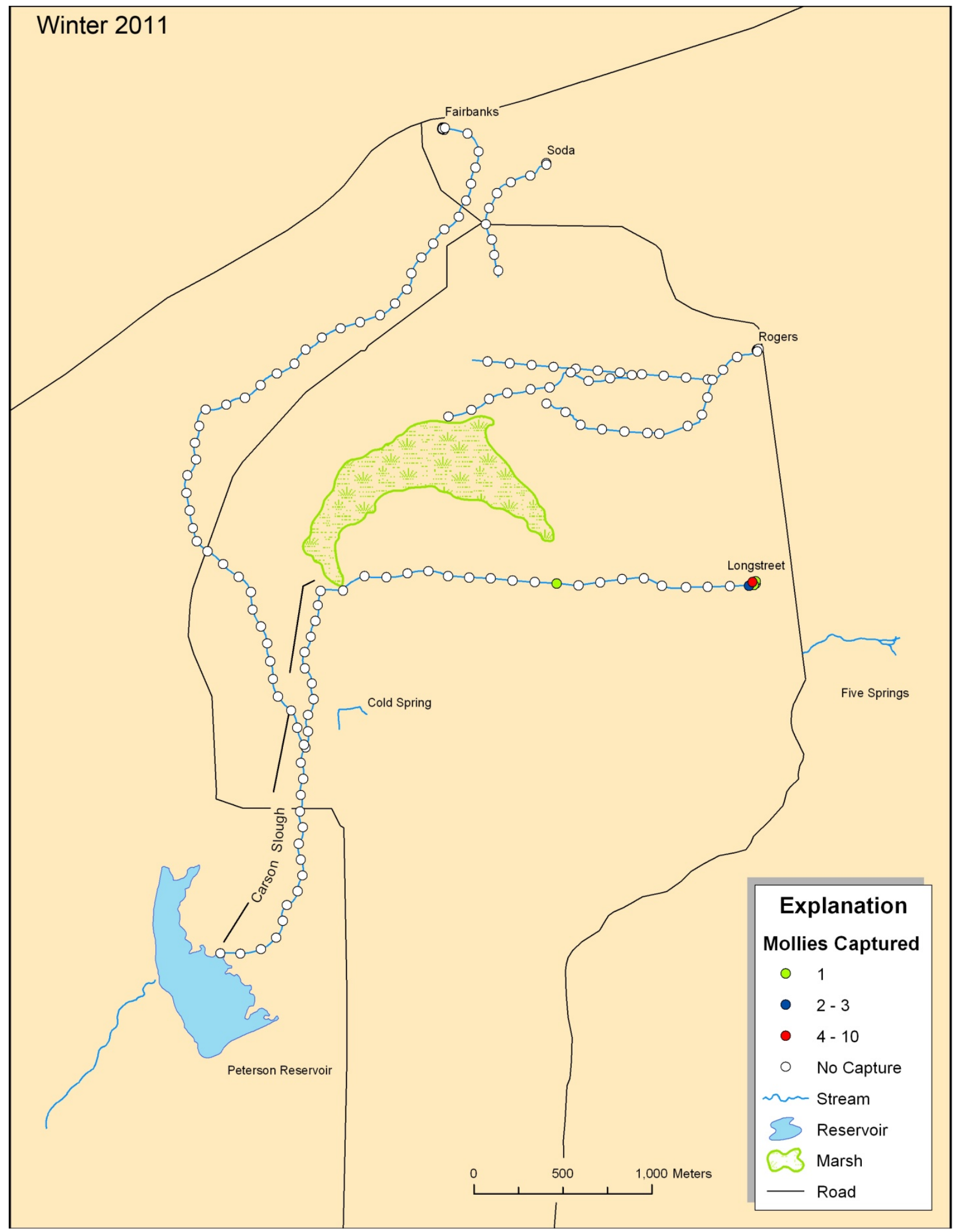

Figure A2. Relative abundance and distribution of sailfin molly in Fairbanks, Soda, Rogers, and Longstreet springs Ash Meadows, National Wildlife Refuge, Nevada, winter 2011. 


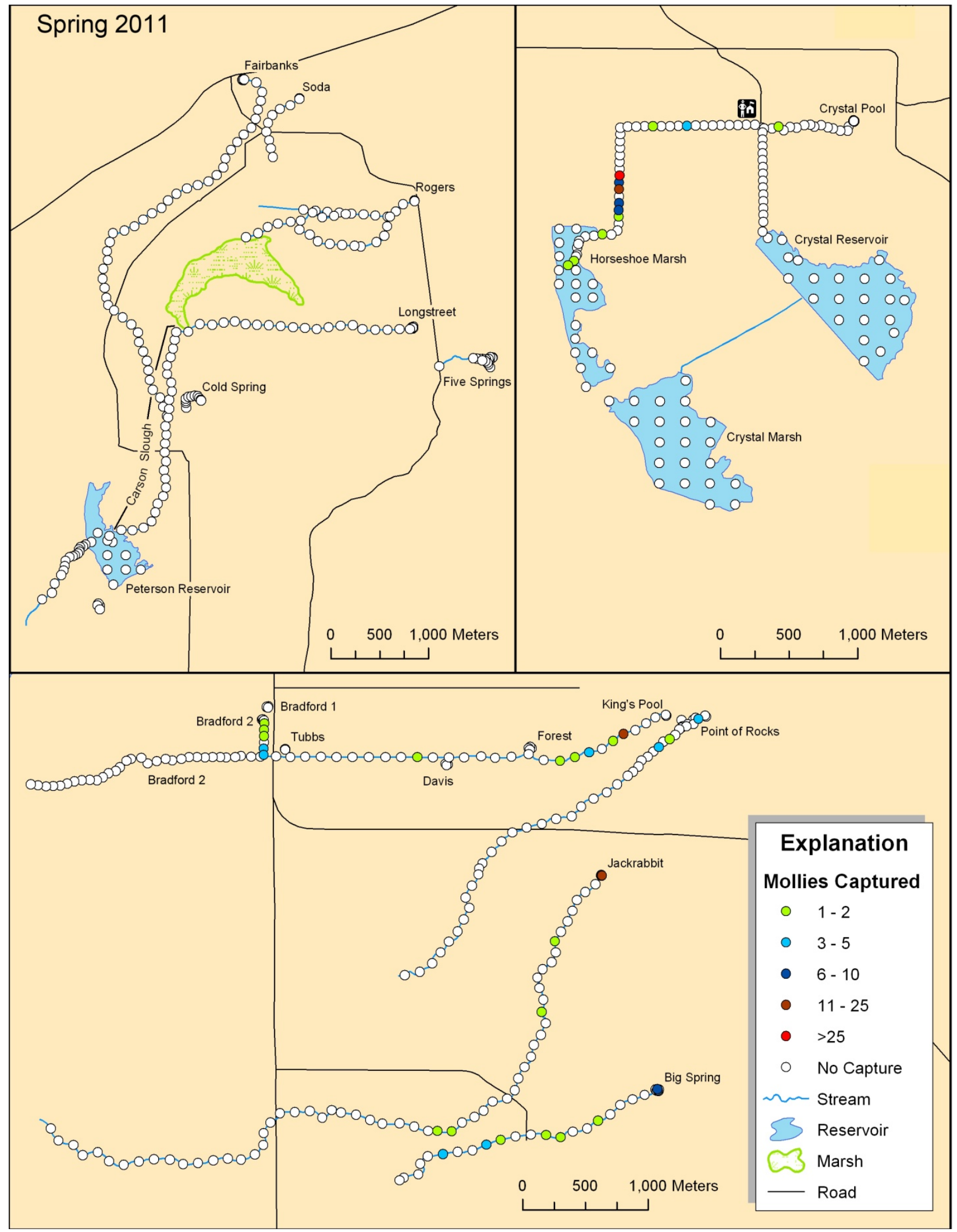

Figure A3. Relative abundance and distribution of sailfin molly throughout Ash Meadows National Wildlife Refuge, Nevada, spring 2011. 


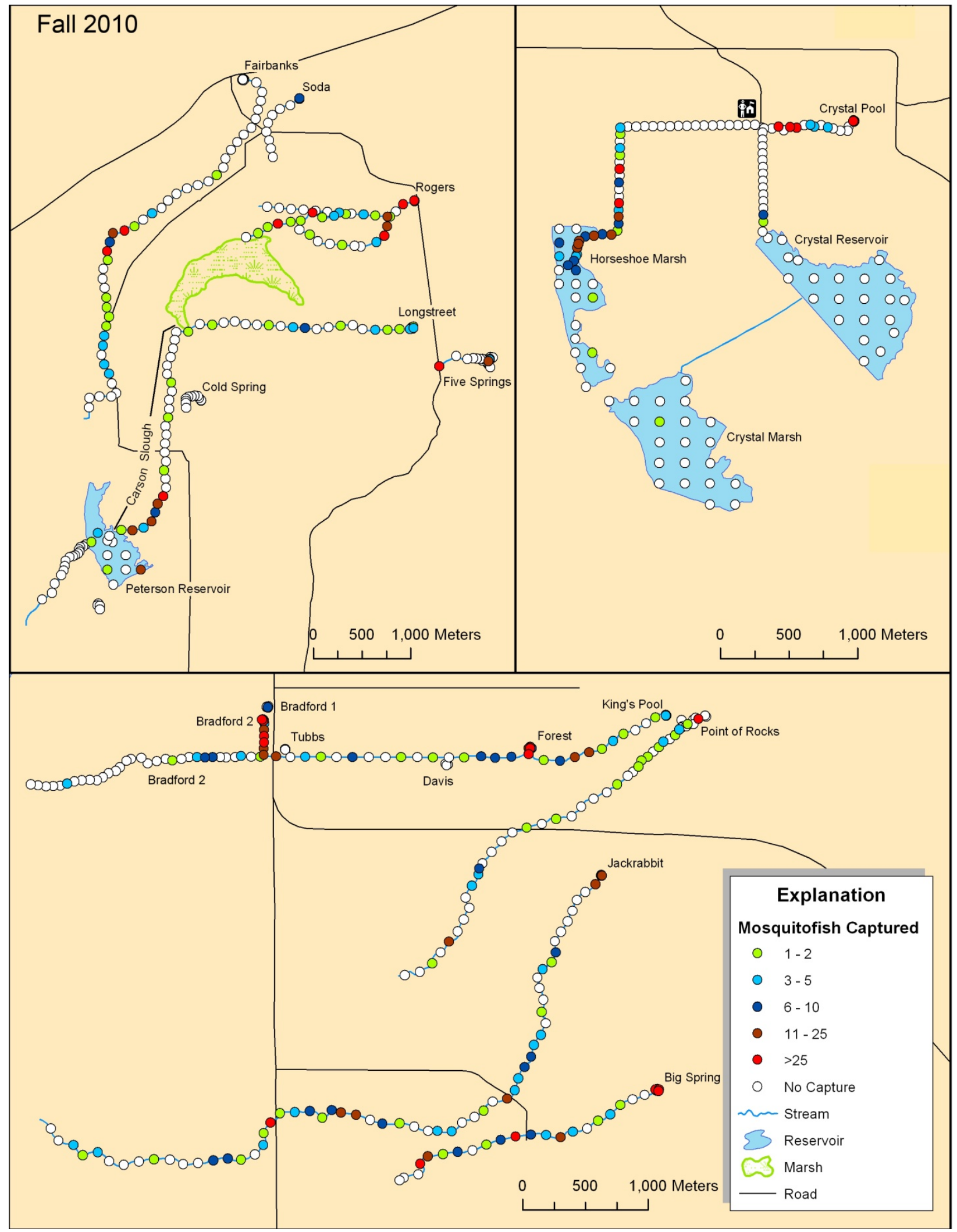

Figure A4. Relative abundance and distribution of mosquitofish throughout Ash Meadows National Wildlife Refuge, Nevada, fall 2010. 


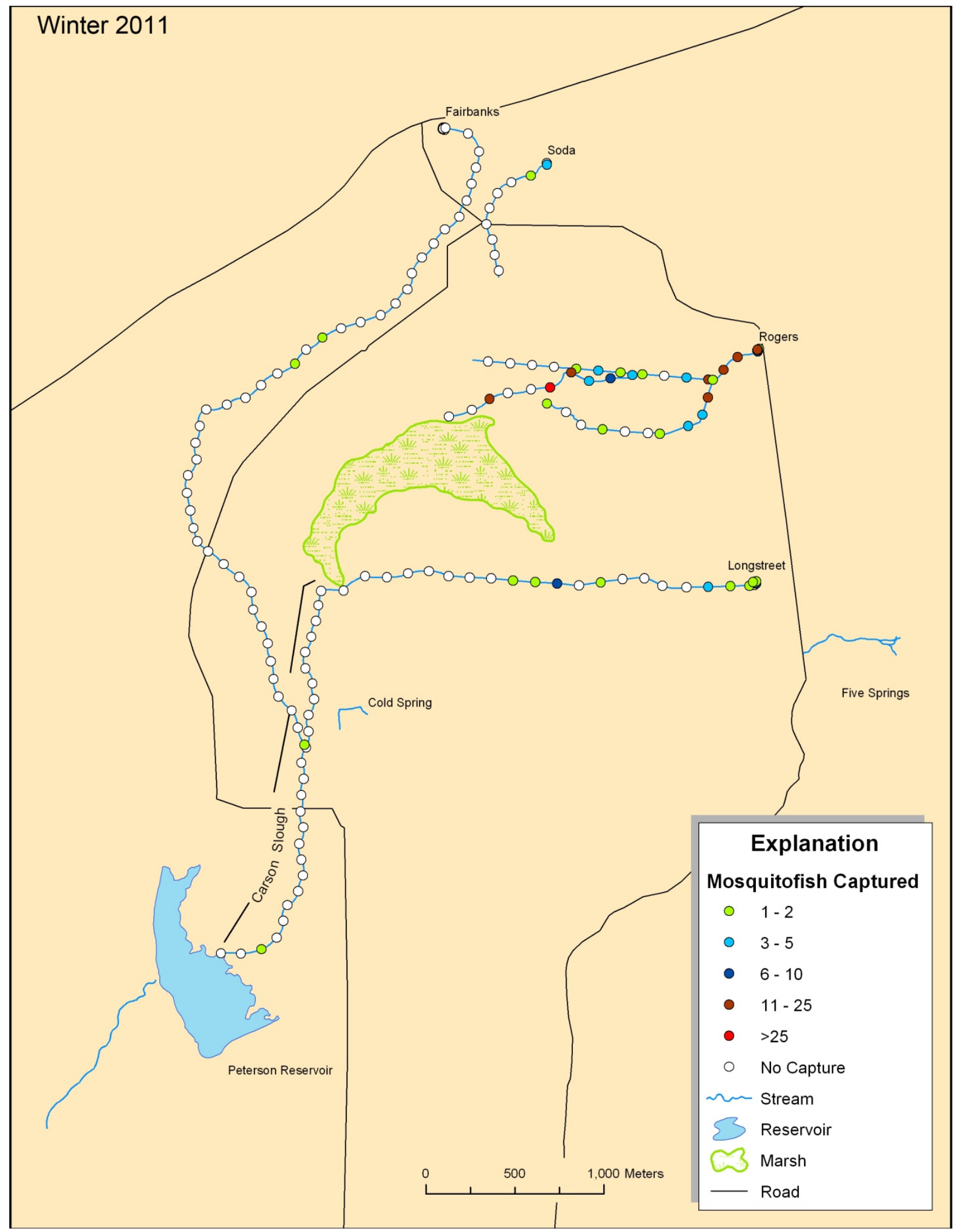

Figure A5. Relative abundance and distribution of mosquitofish in Fairbanks, Soda, Rogers, and Longstreet Springs, Ash Meadows, National Wildlife Refuge, Nevada, winter 2011. 


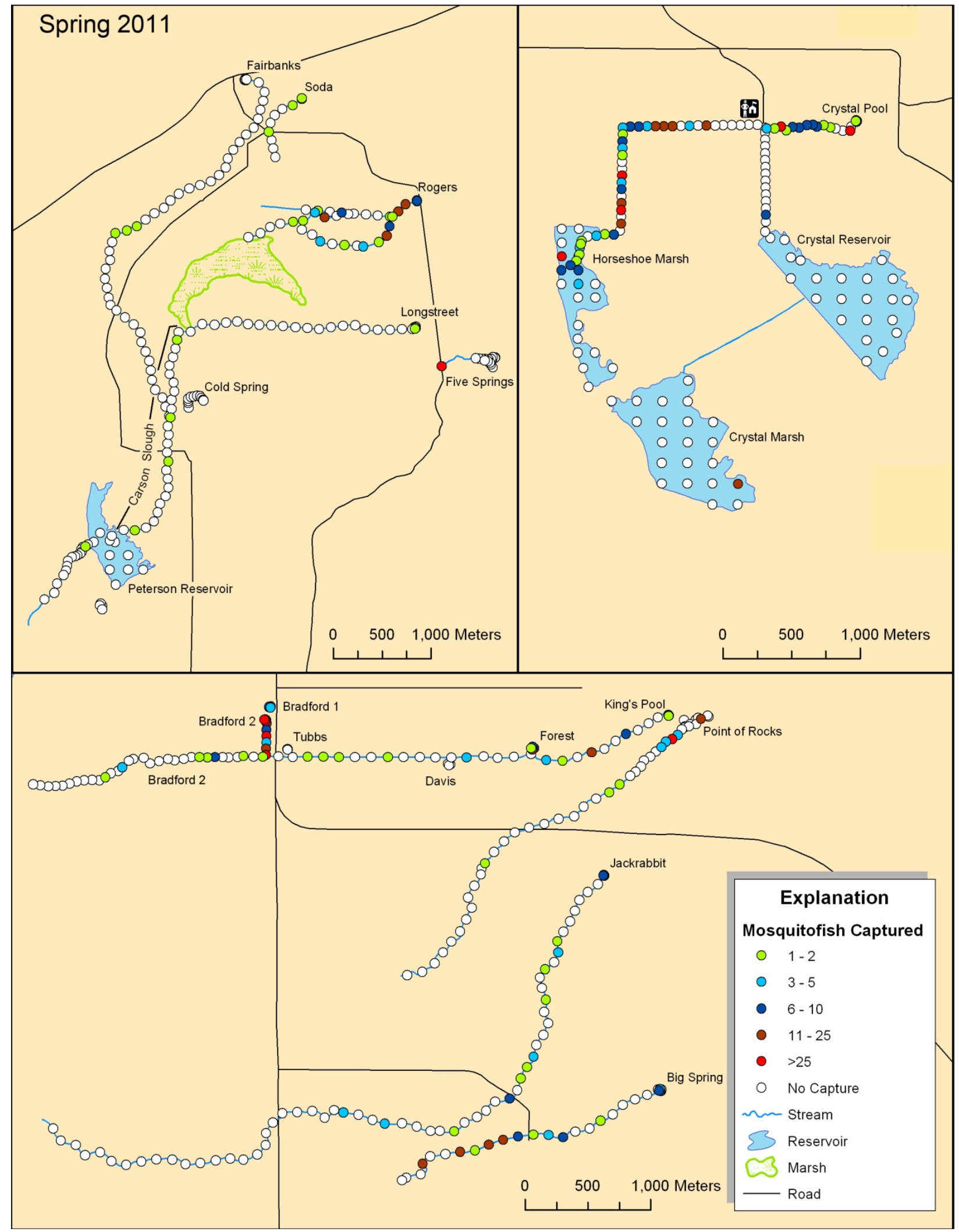

Figure A6. Relative abundance and distribution of mosquitofish throughout Ash Meadows National Wildlife Refuge, Nevada, spring 2011. 


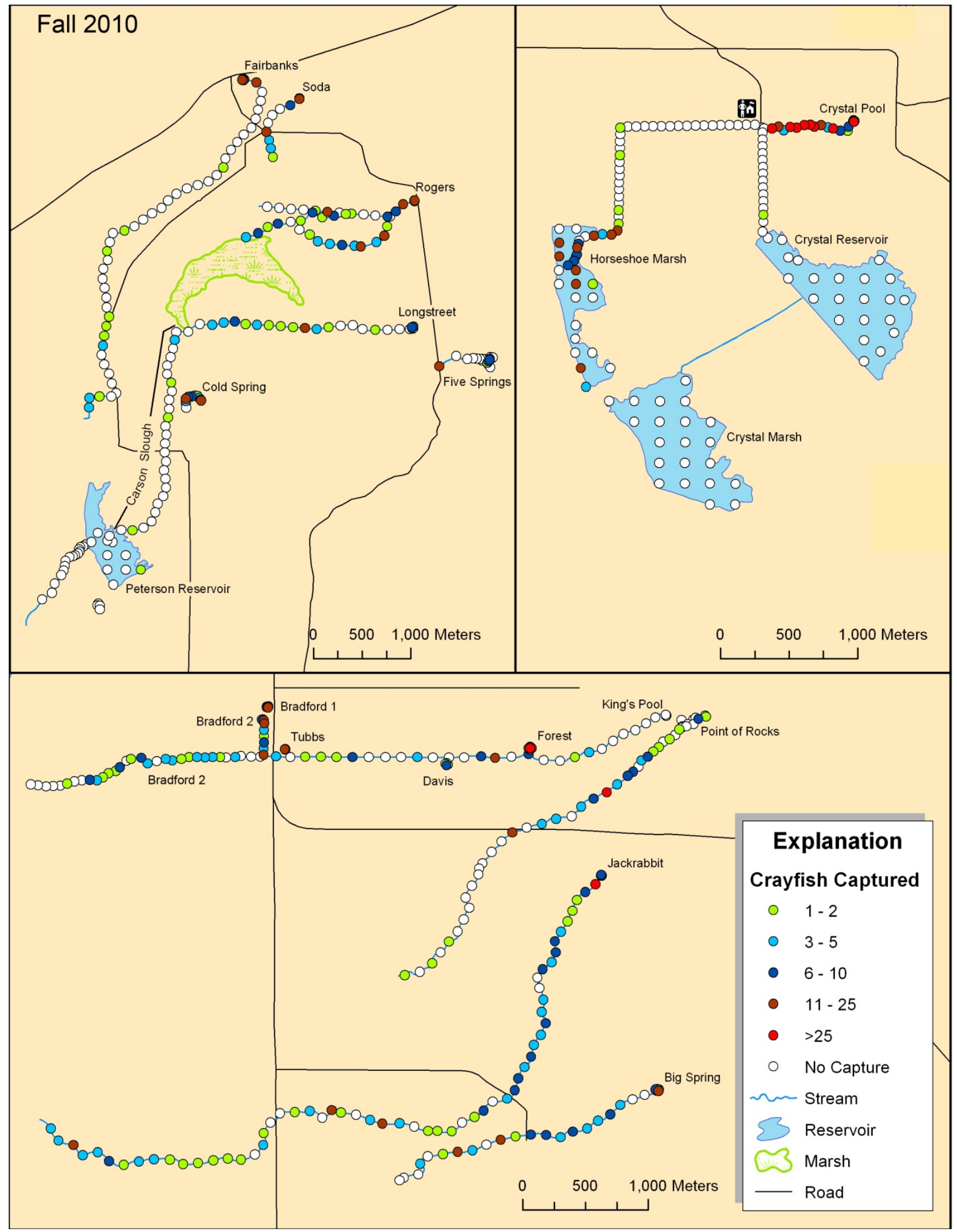

Figure A7. Relative abundance and distribution of crayfish throughout Ash Meadows National Wildlife Refuge, Nevada, fall 2010. 


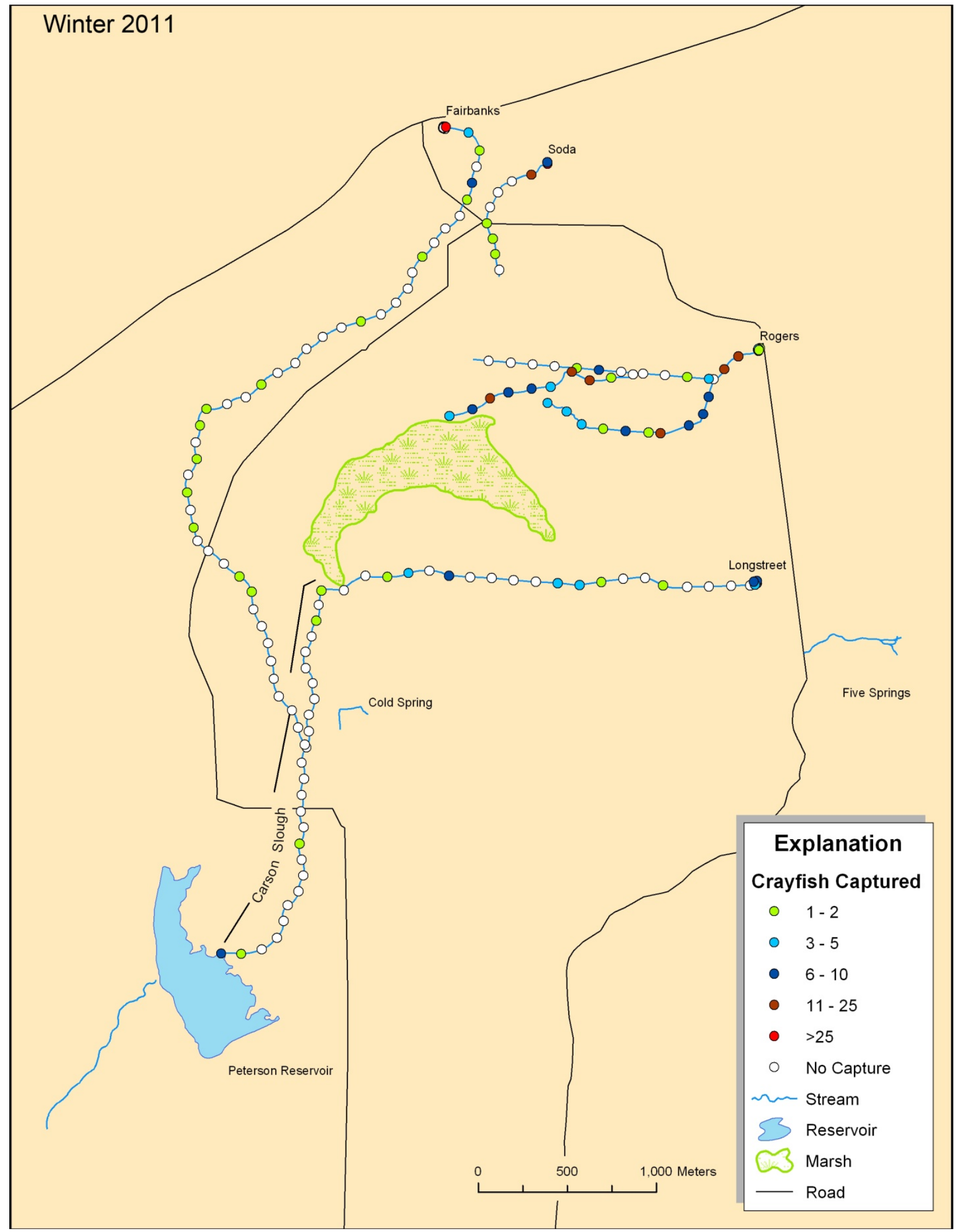

Figure A8. Relative abundance and distribution of crayfish in Fairbanks, Soda, Rogers, and Longstreet Springs, Ash Meadows, National Wildlife Refuge, Nevada, winter 2011. 


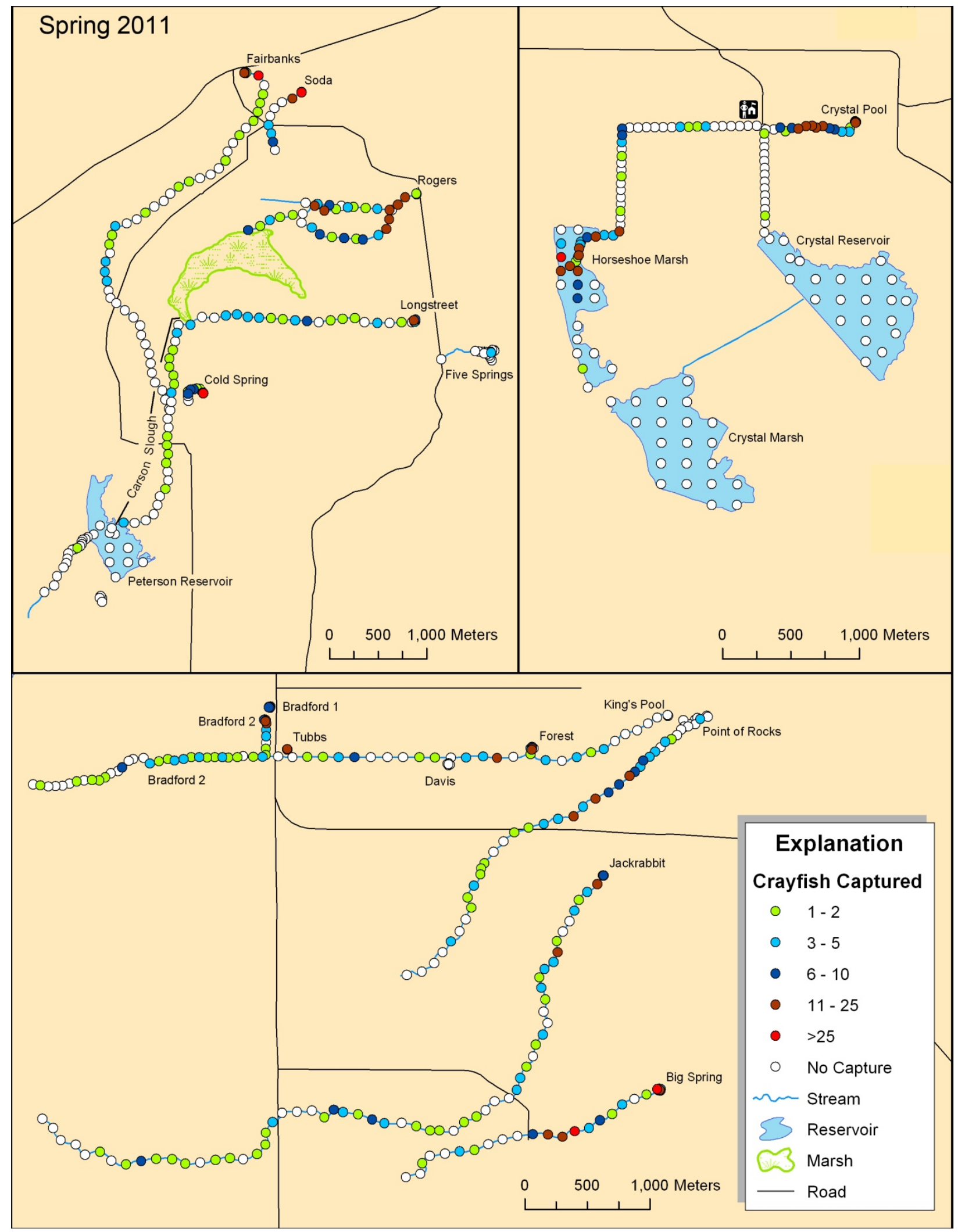

Figure A9. Relative abundance and distribution of crayfish throughout Ash Meadows National Wildlife Refuge, Nevada, spring 2011. 


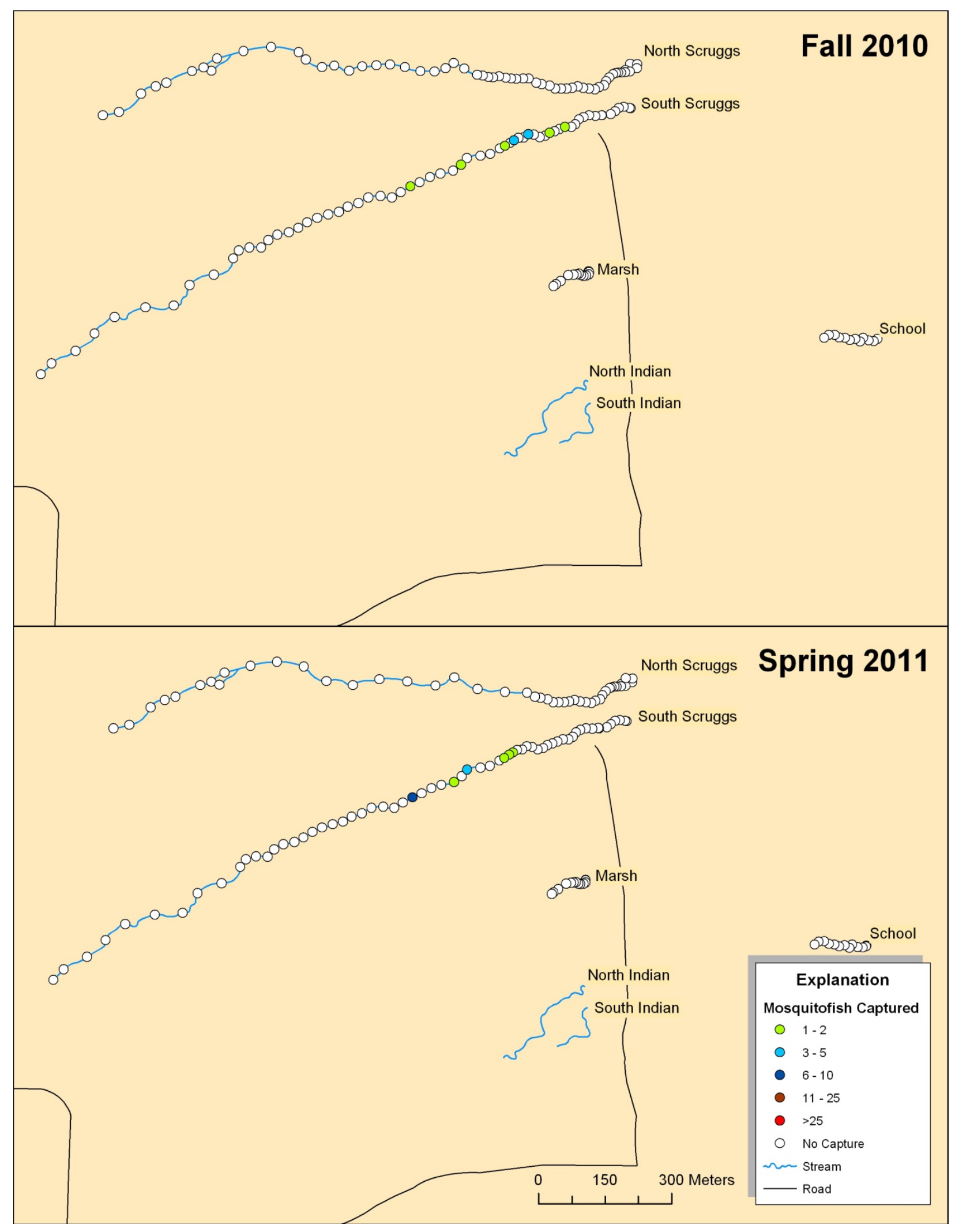

Figure A10. Relative abundance and distribution of mosquitofish in North Scruggs, South Scruggs, Marsh, and School Springs, Ash Meadows National Wildlife Refuge, Nevada, fall 2010 and spring 2011. 


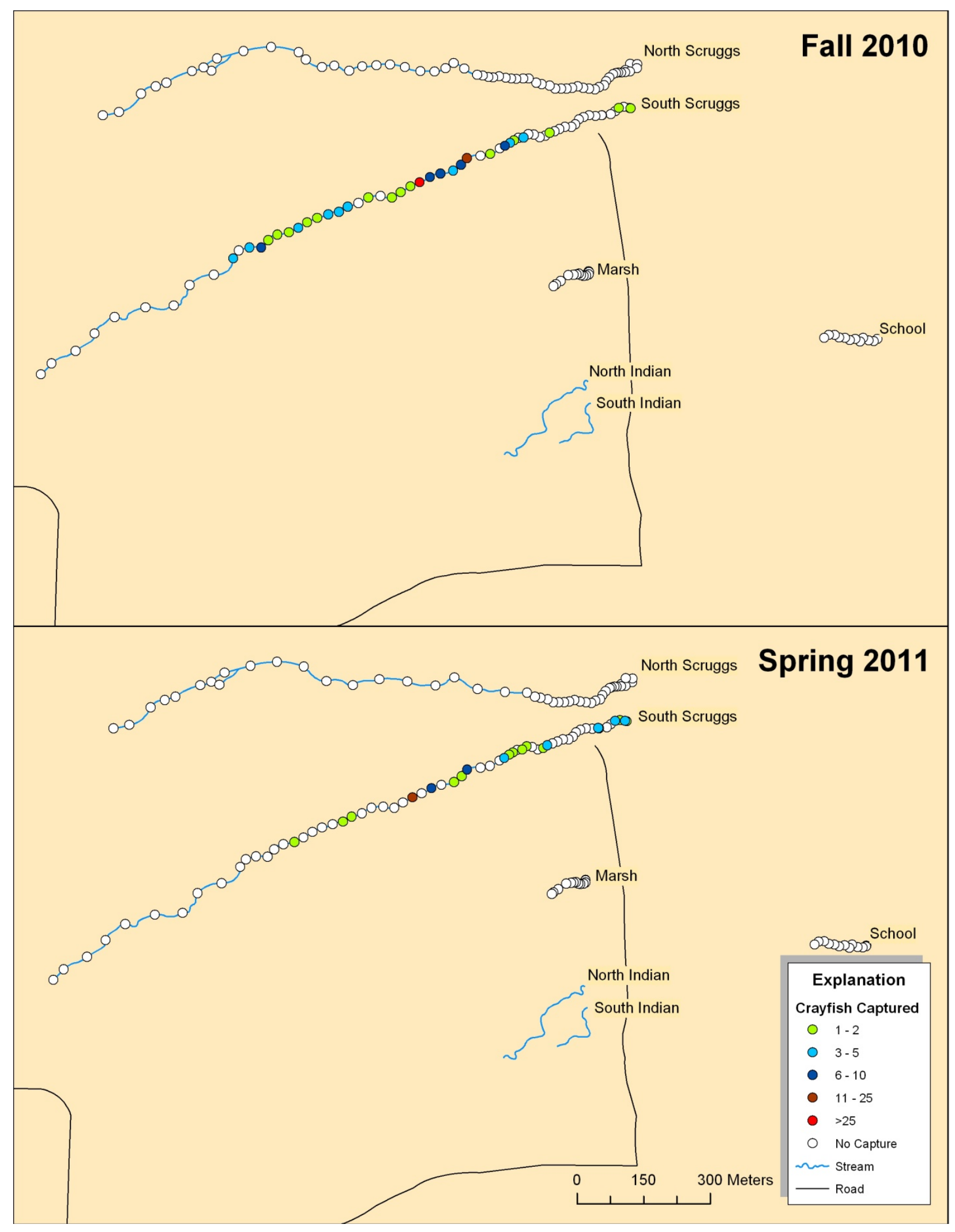

Figure A11. Relative abundance and distribution of crayfish in North Scruggs, South Scruggs, Marsh, and School Springs, Ash Meadows National Wildlife Refuge, Nevada, fall 2010 and spring 2011. 
Table A1. Number and size of individuals of species captured seasonally at the Northern Springs of Ash Meadows National Wildlife Refuge, Nevada.

[Spring locations are shown in figure 1. FL, fork length. Species: CYMI - Ash Meadows pupfish, CYPE - Warm Springs pupfish, GAAF - Mosquitofish, LECY - Green Sunfish, MISA - Largemouth Bass, POLA - Sailfin Molly, PRCL - Red Swamp Crayfish, RACA - Bullfrog, RHON - Ash Meadows speckled dace]

Fall 2010

\begin{tabular}{|c|c|c|c|c|c|c|}
\hline System & Species & Total Catch & Average/trap & $\mathbf{n}$ & $\begin{array}{l}\text { FL (min- } \\
\text { max) }\end{array}$ & $\begin{array}{c}\text { Average } \pm \text { Standard } \\
\text { Deviation }\end{array}$ \\
\hline \multirow{2}{*}{ Fairbanks spring-pool } & CYMI & 426 & 71 & 83 & $16-45$ & $31 \pm 6$ \\
\hline & PRCL & 62 & 10.3 & 60 & $18-68$ & $53 \pm 10$ \\
\hline \multirow{5}{*}{ Fairbanks stream } & CYMI & 1264 & 28.1 & 261 & $18-50$ & $33 \pm 6$ \\
\hline & RHON & 120 & 2.7 & 68 & $24-83$ & $58 \pm 12$ \\
\hline & GAAF & 149 & 3.3 & 65 & $23-48$ & $33 \pm 5$ \\
\hline & RACA & 1 & - & - & - & - \\
\hline & PRCL & 41 & 0.9 & 37 & $28-75$ & $53 \pm 14$ \\
\hline \multirow{3}{*}{ Soda spring-pool } & CYMI & 3 & 3 & 3 & $29-32$ & $30 \pm 2$ \\
\hline & GAAF & 10 & 10 & 9 & $20-35$ & $28 \pm 5$ \\
\hline & PRCL & 3 & 3 & 3 & $35-50$ & $43 \pm 8$ \\
\hline \multirow{4}{*}{ Soda stream } & CYMI & 251 & 27.9 & 66 & $15-47$ & $28 \pm 7$ \\
\hline & GAAF & 0 & - & - & - & - \\
\hline & RACA & 2 & 0.2 & 2 & $80-95$ & $88 \pm 11$ \\
\hline & PRCL & 41 & 4.6 & 37 & $19-76$ & $43 \pm 16$ \\
\hline \multirow{4}{*}{ Roger spring-pool } & CYMI & 125 & 20.8 & 78 & $16-78$ & $30 \pm 9$ \\
\hline & GAAF & 66 & 11 & 47 & $20-41$ & $27 \pm 5$ \\
\hline & RACA & 6 & 1 & 6 & $72-95$ & $83 \pm 8$ \\
\hline & PRCL & 31 & 5.2 & 31 & $30-66$ & $48 \pm 10$ \\
\hline \multirow{3}{*}{ Roger stream } & CYMI & 14 & 0.5 & 14 & $26-55$ & $37 \pm 7$ \\
\hline & GAAF & 205 & 6.8 & 94 & $15-50$ & $32 \pm 6$ \\
\hline & PRCL & 150 & 5 & 122 & $20-72$ & $49 \pm 10$ \\
\hline \multirow{4}{*}{ Longstreet spring-pool } & CYMI & 319 & 53.2 & 20 & $18-50$ & $33 \pm 9$ \\
\hline & GAAF & 5 & 0.8 & 5 & $25-44$ & $35 \pm 9$ \\
\hline & POLA & 5 & 0.8 & 2 & $26-33$ & $30 \pm 5$ \\
\hline & PRCL & 16 & 2.7 & 16 & $32-73$ & $55 \pm 12$ \\
\hline \multirow{5}{*}{ Longstreet stream } & CYMI & 27 & 1.4 & 27 & $15-45$ & $31 \pm 8$ \\
\hline & RHON & 0 & - & - & - & - \\
\hline & GAAF & 30 & 1.5 & 30 & $25-53$ & $37 \pm 7$ \\
\hline & POLA & 1 & 0.1 & 1 & $21-21$ & $21 \pm 0$ \\
\hline & PRCL & 51 & 2.6 & 41 & $28-70$ & $50 \pm 10$ \\
\hline \multirow{4}{*}{ Carson Slough } & CYMI & 157 & 6 & 67 & $17-41$ & $25 \pm 6$ \\
\hline & RHON & 0 & - & - & - & - \\
\hline & GAAF & 115 & 4.4 & 56 & $22-48$ & $29 \pm 4$ \\
\hline & PRCL & 6 & 0.2 & 6 & $40-68$ & $54 \pm 9$ \\
\hline \multirow{3}{*}{ Five Springs spring-pool } & CYMI & 24 & 4.8 & 21 & $22-34$ & $27 \pm 3$ \\
\hline & GAAF & 4 & 0.8 & 4 & $17-22$ & $20 \pm 2$ \\
\hline & PRCL & 8 & 1.6 & 8 & $17-47$ & $37 \pm 10$ \\
\hline \multirow{3}{*}{ Five Springs stream } & CYMI & 6 & 0.4 & 5 & $24-33$ & $28 \pm 3$ \\
\hline & GAAF & 43 & 3.1 & 20 & $17-51$ & $30 \pm 8$ \\
\hline & PRCL & 34 & 2.4 & 20 & $18-67$ & $45 \pm 16$ \\
\hline \multirow{3}{*}{ Peterson reservoir } & CYMI & 29 & 2.9 & 29 & $20-35$ & $26 \pm 3$ \\
\hline & GAAF & 19 & 1.9 & 18 & $24-34$ & $28 \pm 3$ \\
\hline & PRCL & 1 & 0.1 & 1 & $70-70$ & $70 \pm 0$ \\
\hline \multirow{4}{*}{ Peterson stream } & CYMI & \multirow{4}{*}{\multicolumn{5}{|c|}{ No water due to low reservoir level }} \\
\hline & RHON & & & & & \\
\hline & GAAF & & & & & \\
\hline & PRCL & & & & & \\
\hline Cold spring-pool & PRCL & 21 & 21 & 21 & $30-85$ & $53 \pm 12$ \\
\hline \multirow{2}{*}{ Cold stream } & CYMI & 1 & 0.1 & 1 & $39-39$ & $39 \pm 0$ \\
\hline & PRCL & 51 & 6.4 & 47 & $30-68$ & $50 \pm 10$ \\
\hline Cold pool & PRCL & 5 & - & - & - & - \\
\hline
\end{tabular}


Table A1. Number and size of individuals of species captured seasonally at the Northern Springs of Ash Meadows National Wildlife Refuge, Nevada.—Continued

Winter 2011

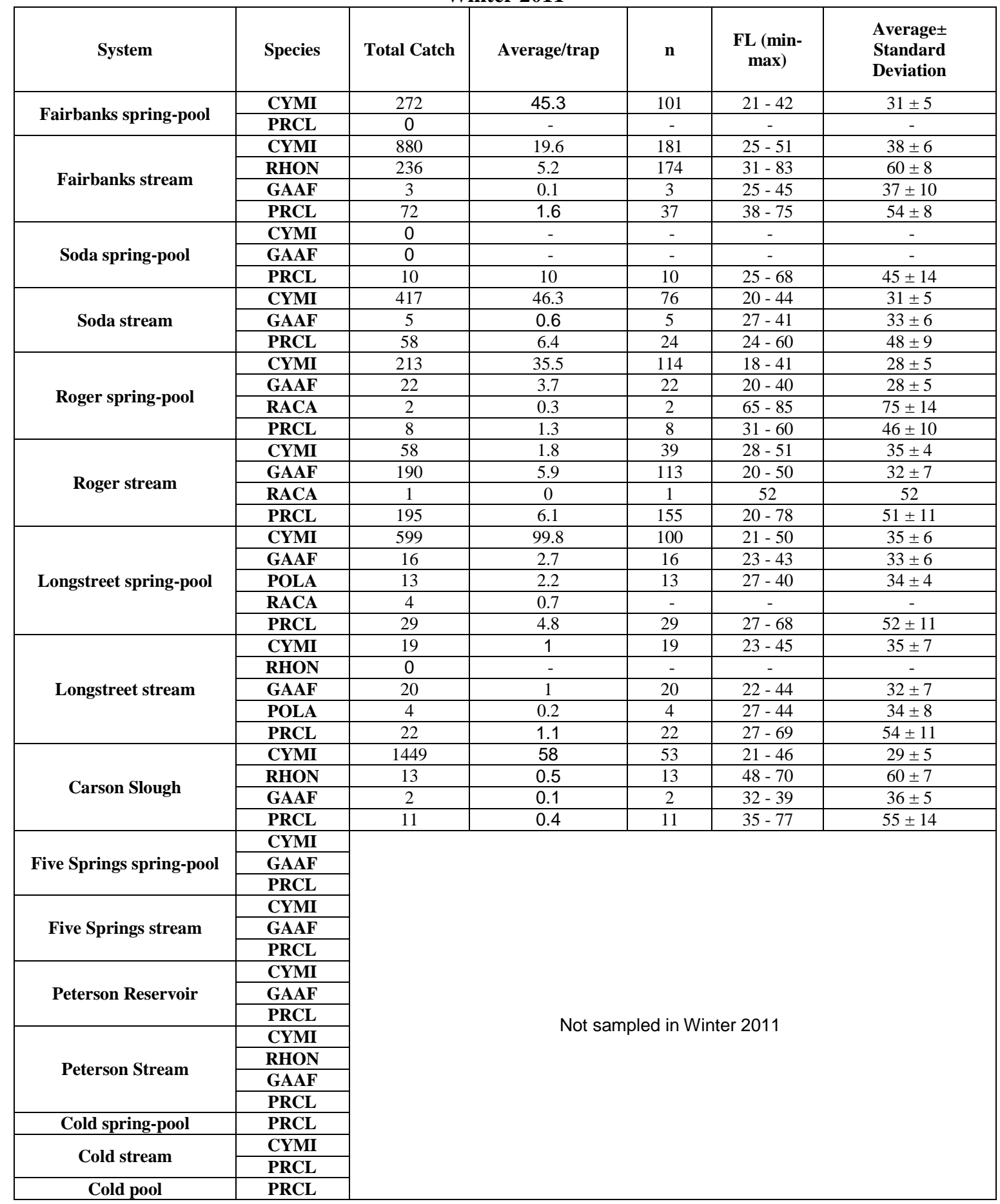


Table A1. Number and size of individuals of species captured seasonally at the Northern Springs of Ash Meadows National Wildlife Refuge, Nevada._Continued

Spring 2011

\begin{tabular}{|c|c|c|c|c|c|c|}
\hline System & Species & Total Catch & Average/trap & $\mathbf{n}$ & $\begin{array}{l}\text { FL (min- } \\
\text { max) }\end{array}$ & $\begin{array}{c}\text { Average } \pm \\
\text { Standard Deviation }\end{array}$ \\
\hline \multirow{2}{*}{ Fairbanks spring-pool } & CYMI & 417 & 69.5 & 114 & $21-50$ & $33 \pm 5$ \\
\hline & PRCL & 31 & 5.2 & 29 & $22-62$ & $46 \pm 8$ \\
\hline \multirow{5}{*}{ Fairbanks stream } & CYMI & 2491 & 55.4 & 288 & $21-58$ & $35 \pm 6$ \\
\hline & RHON & 166 & 3.7 & 146 & $24-77$ & $51 \pm 14$ \\
\hline & GAAF & 5 & 0.1 & 5 & $27-40$ & $31 \pm 5$ \\
\hline & RACA & 1 & - & - & - & - \\
\hline & PRCL & 56 & 1.2 & 39 & $30-84$ & $56 \pm 12$ \\
\hline \multirow{3}{*}{ Soda spring-pool } & CYMI & 12 & 12 & 10 & $21-34$ & $26 \pm 5$ \\
\hline & GAAF & 2 & 2 & 2 & $23-26$ & $25 \pm 2$ \\
\hline & PRCL & 24 & 24 & 10 & $50-62$ & $56 \pm 4$ \\
\hline \multirow{3}{*}{ Soda stream } & CYMI & 363 & 40.3 & 79 & $22-47$ & $31 \pm 4$ \\
\hline & GAAF & 3 & 0.3 & 2 & $40-42$ & $41 \pm 1$ \\
\hline & PRCL & 58 & 6.4 & 36 & $32-68$ & $50 \pm 8$ \\
\hline \multirow{4}{*}{ Roger spring-pool } & CYMI & 227 & 37.8 & 80 & $18-40$ & $29 \pm 5$ \\
\hline & GAAF & 21 & 3.5 & 21 & $19-32$ & $23 \pm 3$ \\
\hline & RACA & 10 & 1.7 & 0 & - & - \\
\hline & PRCL & 2 & 0.3 & 2 & $42-50$ & $46 \pm 6$ \\
\hline \multirow{3}{*}{ Roger spring } & CYMI & 32 & 1.1 & 32 & $23-52$ & $36 \pm 5$ \\
\hline & GAAF & 97 & 3.2 & 77 & $21-53$ & $32 \pm 6$ \\
\hline & PRCL & 176 & 5.9 & 139 & $21-79$ & $56 \pm 11$ \\
\hline \multirow{4}{*}{ Longstreet spring-pool } & CYMI & 79 & 13.2 & 79 & $19-47$ & $32 \pm 7$ \\
\hline & GAAF & 1 & 0.2 & 1 & $47-47$ & $47 \pm 0$ \\
\hline & POLA & 0 & - & - & - & - \\
\hline & PRCL & 24 & 4 & 24 & $29-75$ & $45 \pm 14$ \\
\hline \multirow{5}{*}{ Longstreet stream } & CYMI & 17 & 0.9 & 17 & $23-42$ & $34 \pm 6$ \\
\hline & RHON & 1 & 0.1 & 1 & $53-53$ & $53 \pm 0$ \\
\hline & GAAF & 0 & - & - & - & - \\
\hline & POLA & 0 & - & - & - & - \\
\hline & PRCL & 39 & 2 & 39 & $24-72$ & $51 \pm 12$ \\
\hline \multirow{4}{*}{ Carson Slough } & CYMI & 312 & 12 & 111 & $20-51$ & $34 \pm 7$ \\
\hline & RHON & 3 & 0.1 & 3 & $57-73$ & $67 \pm 9$ \\
\hline & GAAF & 4 & 0.2 & 2 & $28-30$ & $29 \pm 1$ \\
\hline & PRCL & 28 & 1.1 & 28 & $31-81$ & $51 \pm 11$ \\
\hline \multirow{3}{*}{$\begin{array}{c}\text { Five Springs spring- } \\
\text { pool }\end{array}$} & CYMI & 12 & 3 & 11 & $20-38$ & $27 \pm 5$ \\
\hline & GAAF & 0 & - & - & - & - \\
\hline & PRCL & 3 & 0.8 & 3 & $34-45$ & $41 \pm 6$ \\
\hline \multirow{3}{*}{ Five Springs stream } & CYMI & 10 & 0.8 & 10 & $23-34$ & $27 \pm 4$ \\
\hline & GAAF & 36 & 3 & 10 & $22-50$ & $35 \pm 10$ \\
\hline & PRCL & 0 & 0 & - & - & - \\
\hline \multirow{3}{*}{ Peterson Reservoir } & CYMI & 8 & 0.7 & 8 & $21-38$ & $28 \pm 5$ \\
\hline & GAAF & 0 & - & - & - & - \\
\hline & PRCL & 0 & - & - & - & - \\
\hline \multirow{4}{*}{ Peterson stream } & CYMI & 124 & 6.2 & 83 & $20-41$ & $29 \pm 5$ \\
\hline & RHON & 2 & 0.1 & 2 & $55-70$ & $63 \pm 11$ \\
\hline & GAAF & 1 & 0.1 & 1 & $31-31$ & $31 \pm 0$ \\
\hline & PRCL & 1 & 0.1 & 1 & $81-81$ & $81 \pm 0$ \\
\hline Cold springs & PRCL & 26 & 26 & 10 & $42-67$ & $51 \pm 8$ \\
\hline \multirow{2}{*}{ Cold stream } & CYMI & 1 & 0.1 & 1 & $47-47$ & $47 \pm 0$ \\
\hline & PRCL & 37 & 4.6 & 37 & $32-63$ & $46 \pm 8$ \\
\hline Cold pool & PRCL & 18 & 18 & 10 & $42-62$ & $52 \pm 7$ \\
\hline
\end{tabular}


Table A2. Number and size of individuals of species captured seasonally at the Warm Springs Complex of Ash Meadows National Wildlife Refuge, Nevada.

[Spring locations are shown in figure 1. FL, fork length. Species: CYMI - Ash Meadows pupfish, CYPE - Warm Springs pupfish, GAAF - Mosquitofish, LECY - Green Sunfish, MISA - Largemouth Bass, POLA - Sailfin Molly, PRCL - Red Swamp Crayfish, RACA - Bullfrog, RHON - Ash Meadows speckled dace]

Fall 2010

\begin{tabular}{|c|c|c|c|c|c|c|}
\hline System & Species & $\begin{array}{l}\text { Total } \\
\text { Catch }\end{array}$ & Average/trap & $\mathbf{n}$ & $\begin{array}{l}\text { FL (min- } \\
\text { max) }\end{array}$ & $\begin{array}{c}\text { Average } \pm \text { Standard } \\
\text { Deviation }\end{array}$ \\
\hline $\begin{array}{c}\text { North Scruggs spring- } \\
\text { pool }\end{array}$ & CYPE & 0 & - & - & - & - \\
\hline North Scruggs stream & CYPE & 95 & 2.2 & 85 & $19-41$ & $30 \pm 5$ \\
\hline \multirow{2}{*}{$\begin{array}{c}\text { South Scruggs spring- } \\
\text { pool }\end{array}$} & CYPE & 1 & 1 & 1 & $24-24$ & $24 \pm 0$ \\
\hline & PRCL & 2 & 2 & 2 & $49-50$ & $50 \pm 1$ \\
\hline \multirow{3}{*}{ South Scruggs stream } & CYPE & 120 & 2.3 & 74 & $18-42$ & $31 \pm 5$ \\
\hline & GAAF & 13 & 0.2 & 13 & $21-43$ & $31 \pm 7$ \\
\hline & PRCL & 131 & 2.5 & 112 & $21-79$ & $49 \pm 14$ \\
\hline Marsh spring-pool & CYPE & 0 & - & - & - & - \\
\hline Marsh stream & CYPE & 64 & 5.3 & 35 & $17-37$ & $28 \pm 6$ \\
\hline $\begin{array}{l}\text { North and South Indian } \\
\text { spring-pools and streams }\end{array}$ & \multicolumn{6}{|c|}{ Not surveyed due to ongoing restoration } \\
\hline School spring-pool & CYPE & 13 & 13 & 10 & $23-30$ & $26 \pm 3$ \\
\hline School Stream & CYPE & 252 & 25.2 & 64 & $17-40$ & $27 \pm 4$ \\
\hline
\end{tabular}

Spring 2011

\begin{tabular}{|c|c|c|c|c|c|c|}
\hline System & Species & $\begin{array}{l}\text { Total } \\
\text { Catch }\end{array}$ & Average/trap & $\mathbf{n}$ & $\begin{array}{l}\text { FL (min- } \\
\text { max) }\end{array}$ & $\begin{array}{l}\text { Average } \pm \\
\text { Standard } \\
\text { Deviation }\end{array}$ \\
\hline North Scruggs spring-pool & CYPE & 0 & - & - & - & - \\
\hline North Scruggs Stream & CYPE & 58 & 1.8 & 58 & $21-46$ & $33 \pm 6$ \\
\hline \multirow{2}{*}{ South Scruggs spring-pool } & CYPE & 0 & - & - & - & - \\
\hline & PRCL & 2 & 2 & 2 & $37-61$ & $49 \pm 17$ \\
\hline \multirow{3}{*}{ South Scruggs stream } & CYPE & 93 & 1.8 & 69 & $19-42$ & $30 \pm 6$ \\
\hline & GAAF & 19 & 0.4 & 19 & $20-42$ & $29 \pm 5$ \\
\hline & PRCL & 69 & 1.3 & 66 & $18-64$ & $45 \pm 11$ \\
\hline Marsh spring-pool & CYPE & 0 & - & - & - & - \\
\hline Marsh stream & CYPE & 123 & 11.2 & 55 & $20-43$ & $29 \pm 5$ \\
\hline $\begin{array}{l}\text { North and South Indian } \\
\text { spring-pools and streams }\end{array}$ & \multicolumn{6}{|c|}{ Not surveyed due to ongoing restoration } \\
\hline School spring-pool & CYPE & 2 & 2 & 2 & $25-27$ & $26 \pm 1$ \\
\hline School stream & CYPE & 329 & 29.9 & 75 & $19-36$ & $27 \pm 3$ \\
\hline
\end{tabular}


Table A3. Number and size of individuals of species captured seasonally at the Southern Springs of Ash Meadows National Wildlife Refuge, Nevada.

[Spring locations are shown in figure 1. FL, fork length. Species: CYMI - Ash Meadows pupfish, CYPE - Warm Springs pupfish, GAAF - Mosquitofish, LECY - Green Sunfish, MISA - Largemouth Bass, POLA - Sailfin Molly, PRCL - Red Swamp Crayfish, RACA - Bullfrog, RHON - Ash Meadows speckled dace]

Fall 2010

\begin{tabular}{|c|c|c|c|c|c|c|}
\hline System & Species & Total Catch & Average/trap & $\mathbf{n}$ & $\begin{array}{l}\text { FL (min- } \\
\text { max) }\end{array}$ & $\begin{array}{c}\text { Average } \pm \text { Standard } \\
\text { Deviation }\end{array}$ \\
\hline \multirow{3}{*}{ Crystal spring-pool } & CYMI & 455 & 75.8 & 129 & $17-60$ & $30 \pm 7$ \\
\hline & GAAF & 217 & 36.2 & 77 & $18-39$ & $27 \pm 5$ \\
\hline & PRCL & 29 & 4.8 & 29 & $46-70$ & $58 \pm 5$ \\
\hline \multirow{4}{*}{ Crystal stream } & CYMI & 619 & 14.4 & 237 & $17-50$ & $30 \pm 6$ \\
\hline & GAAF & 364 & 8.5 & 199 & $20-46$ & $30 \pm 6$ \\
\hline & POLA & 68 & 1.6 & 40 & $21-65$ & $39 \pm 9$ \\
\hline & PRCL & 561 & 13 & 206 & $27-70$ & $54 \pm 9$ \\
\hline \multirow{2}{*}{ Crystal reservoir } & LECY & 37 & 1.8 & 34 & $26-63$ & $45 \pm 9$ \\
\hline & MISA & 0 & - & - & - & - \\
\hline \multirow{3}{*}{ Crystal marsh } & CYMI & 13 & 1.1 & 13 & $23-25$ & $24 \pm 1$ \\
\hline & GAAF & 1 & 0.1 & 1 & $25-25$ & $25 \pm 0$ \\
\hline & LECY & 52 & 4.3 & 25 & $25-67$ & $40 \pm 12$ \\
\hline \multirow{6}{*}{ Horseshoe marsh } & CYMI & 11 & 0.7 & 11 & $17-40$ & $25 \pm 6$ \\
\hline & GAAF & 35 & 2.3 & 34 & $19-42$ & $29 \pm 5$ \\
\hline & POLA & 14 & 0.9 & 14 & $17-51$ & $28 \pm 10$ \\
\hline & LECY & 1 & 0.1 & 1 & $31-31$ & $31 \pm 0$ \\
\hline & MISA & 1 & 0.1 & 1 & $54-54$ & $54 \pm 0$ \\
\hline & PRCL & 86 & 5.7 & 67 & $15-70$ & $51 \pm 13$ \\
\hline \multirow{3}{*}{ Kings Pool spring-pool } & CYMI & 647 & 107.8 & 125 & $17-49$ & $32 \pm 6$ \\
\hline & GAAF & 6 & 1 & 6 & $23-44$ & $29 \pm 8$ \\
\hline & POLA & 10 & 1.7 & 10 & $22-42$ & $31 \pm 8$ \\
\hline \multirow{4}{*}{ Kings Pool stream } & CYMI & 137 & 4.9 & 81 & $20-48$ & $34 \pm 6$ \\
\hline & GAAF & 123 & 4.4 & 99 & $21-48$ & $30 \pm 7$ \\
\hline & POLA & 19 & 0.7 & 19 & $21-51$ & $36 \pm 7$ \\
\hline & PRCL & 59 & 2.1 & 51 & $21-68$ & $50 \pm 10$ \\
\hline \multirow{5}{*}{ Point of Rocks stream } & CYMI & 252 & 6 & 131 & $13-55$ & $27 \pm 7$ \\
\hline & RHON & 3 & 0.1 & 3 & $38-52$ & $43 \pm 8$ \\
\hline & GAAF & 85 & 2 & 57 & $21-46$ & $30 \pm 6$ \\
\hline & POLA & 9 & 0.2 & 9 & $29-52$ & $37 \pm 7$ \\
\hline & PRCL & 113 & 2.7 & 91 & $28-69$ & $50 \pm 9$ \\
\hline \multirow{3}{*}{ Bradford 1 spring-pool } & RHON & 145 & 24.2 & 104 & $25-74$ & $44 \pm 8$ \\
\hline & GAAF & 9 & 1.5 & 9 & $19-42$ & $26 \pm 7$ \\
\hline & PRCL & 58 & 9.7 & 58 & $25-76$ & $43 \pm 9$ \\
\hline Bradford 1 stream & \multicolumn{6}{|c|}{ There is no longer an outflow channel } \\
\hline \multirow{4}{*}{ Bradford 2 spring-pool } & RHON & 0 & - & - & - & - \\
\hline & GAAF & 466 & 77.7 & 130 & $16-39$ & $27 \pm 7$ \\
\hline & RACA & 1 & 0.2 & 1 & $77-77$ & $77 \pm 0$ \\
\hline & PRCL & 20 & 3.3 & 20 & $20-73$ & $45 \pm 15$ \\
\hline \multirow{5}{*}{ Bradford 2 stream } & CYMI & 12 & 0.3 & 12 & $17-47$ & $34 \pm 10$ \\
\hline & RHON & 16 & 0.4 & 16 & $31-72$ & $59 \pm 13$ \\
\hline & GAAF & 174 & 4.7 & 88 & $20-51$ & $37 \pm 8$ \\
\hline & POLA & 15 & 0.4 & 15 & $33-64$ & $47 \pm 10$ \\
\hline & PRCL & 131 & 3.5 & 115 & $20-74$ & $54 \pm 13$ \\
\hline \multirow{4}{*}{ Forest spring-pool } & CYMI & 9 & 1.5 & 8 & $25-46$ & $37 \pm 7$ \\
\hline & GAAF & 235 & 39.2 & 112 & $14-44$ & $26 \pm 7$ \\
\hline & POLA & 7 & 1.2 & 7 & $17-32$ & $22 \pm 5$ \\
\hline & PRCL & 75 & 12.5 & 70 & $21-73$ & $46 \pm 10$ \\
\hline \multirow{2}{*}{ Tubbs spring-pool } & RHON & 1 & 0.2 & 1 & $58-58$ & $58 \pm 0$ \\
\hline & PRCL & 67 & 11.2 & 66 & $25-79$ & $55 \pm 11$ \\
\hline Davis spring-pool & PRCL & 11 & 1.8 & 11 & $16-74$ & $53 \pm 19$ \\
\hline
\end{tabular}


Table A3. Number and size of individuals of species captured seasonally at the Southern Springs of Ash Meadows National Wildlife Refuge, Nevada.-Continued.

Fall 2010

\begin{tabular}{|c|c|c|c|c|c|c|}
\hline System & Species & Total Catch & Average/trap & n & $\begin{array}{c}\text { FL (min- } \\
\text { max) }\end{array}$ & $\begin{array}{c}\text { Average } \pm \text { Standard } \\
\text { Deviation }\end{array}$ \\
\hline \multirow{4}{*}{$\begin{array}{c}\text { Jackrabbit spring- } \\
\text { pool }\end{array}$} & CYMI & 474 & 79 & 125 & $18-52$ & $34 \pm 7$ \\
\cline { 2 - 7 } & RHON & 3 & 0.5 & 3 & $51-52$ & $51 \pm 1$ \\
\cline { 2 - 7 } & GAAF & 42 & 7 & 42 & $18-50$ & $31 \pm 8$ \\
\cline { 2 - 7 } & POLA & 3 & 0.5 & 3 & $21-47$ & $31 \pm 14$ \\
\cline { 2 - 7 } & PRCL & 14 & 2.3 & 14 & $32-55$ & $43 \pm 7$ \\
\hline \multirow{5}{*}{ Jackrabbit stream } & CYMI & 118 & 2 & 106 & $19-52$ & $35 \pm 7$ \\
\cline { 2 - 7 } & RHON & 623 & 10.4 & 414 & $18-82$ & $53 \pm 13$ \\
\cline { 2 - 7 } & GAAF & 224 & 3.7 & 169 & $15-61$ & $36 \pm 8$ \\
\cline { 2 - 7 } & POLA & 4 & 0.1 & 4 & $21-51$ & $34 \pm 13$ \\
\cline { 2 - 7 } & PRCL & 261 & 4.4 & 220 & $21-71$ & $50 \pm 10$ \\
\hline \multirow{5}{*}{ Big Spring spring-pool } & CYMI & 221 & 36.8 & 125 & $22-55$ & $35 \pm 6$ \\
\cline { 2 - 7 } & GAAF & 106 & 17.7 & 79 & $20-41$ & $27 \pm 4$ \\
\cline { 2 - 7 } & POLA & 21 & 3.5 & 21 & $26-54$ & $37 \pm 7$ \\
\cline { 2 - 7 } & PRCL & 23 & 3.8 & 23 & $28-64$ & $49 \pm 11$ \\
\hline & CYMI & 54 & 2.8 & 43 & $21-45$ & $33 \pm 7$ \\
\cline { 2 - 7 } & GAAF & 195 & 10.3 & 93 & $15-45$ & $31 \pm 6$ \\
\cline { 2 - 7 } & POLA & 18 & 0.9 & 18 & $18-51$ & $33 \pm 8$ \\
\cline { 2 - 7 } & RACA & 1 & - & - & - & - \\
\cline { 2 - 7 } & PRCL & 94 & 4.9 & 91 & $25-71$ & $48 \pm 10$ \\
\hline
\end{tabular}

Spring 2011

\begin{tabular}{|c|c|c|c|c|c|c|}
\hline \multirow{3}{*}{ Crystal spring-pool } & CYMI & 78 & 13 & 45 & $14-33$ & $23 \pm 4$ \\
\hline & GAAF & 16 & 2.7 & 16 & $21-33$ & $25 \pm 4$ \\
\hline & PRCL & 0 & - & - & - & - \\
\hline \multirow{2}{*}{ Crystal stream } & CYMI & 1499 & 28.3 & 328 & $18-54$ & $33 \pm 8$ \\
\hline & PRCL & 273 & 5.2 & 213 & $19-78$ & $54 \pm 12$ \\
\hline \multirow{2}{*}{ Crystal reservoir } & LECY & 1 & - & - & $42-42$ & $42 \pm 0$ \\
\hline & MISA & 3 & 0.1 & 3 & $340-370$ & $350 \pm 17$ \\
\hline \multirow[b]{2}{*}{ Crystal marsh } & CYMI & 1 & 0.1 & 1 & $28-28$ & $28 \pm 0$ \\
\hline & GAAF & 22 & 1.7 & 10 & $25-40$ & $31 \pm 5$ \\
\hline \multirow{4}{*}{ Horseshoe marsh } & POLA & 0 & - & - & - & - \\
\hline & LECY & 1 & 0.1 & 1 & $52-52$ & $52 \pm 0$ \\
\hline & MISA & 0 & - & - & - & - \\
\hline & PRCL & 100 & 6.3 & 61 & $24-72$ & $49 \pm 12$ \\
\hline \multirow{3}{*}{$\begin{array}{c}\text { Kings Pool spring- } \\
\text { pool }\end{array}$} & CYMI & 635 & 105.8 & 117 & $19-49$ & $32 \pm 6$ \\
\hline & GAAF & 21 & 3.5 & 21 & $23-42$ & $32 \pm 6$ \\
\hline & POLA & 0 & - & - & - & - \\
\hline \multirow{4}{*}{ Kings Pool stream } & CYMI & 78 & 2.8 & 52 & $23-46$ & $37 \pm 5$ \\
\hline & GAAF & 33 & 1.2 & 32 & $22-47$ & $33 \pm 9$ \\
\hline & POLA & 20 & 0.7 & 19 & $27-52$ & $36 \pm 6$ \\
\hline & PRCL & 60 & 2.1 & 50 & $26-74$ & $53 \pm 11$ \\
\hline
\end{tabular}


Table A3. Number and size of individuals of species captured seasonally at the Southern Springs of Ash Meadows National Wildlife Refuge, Nevada.-Continued.

Spring 2011

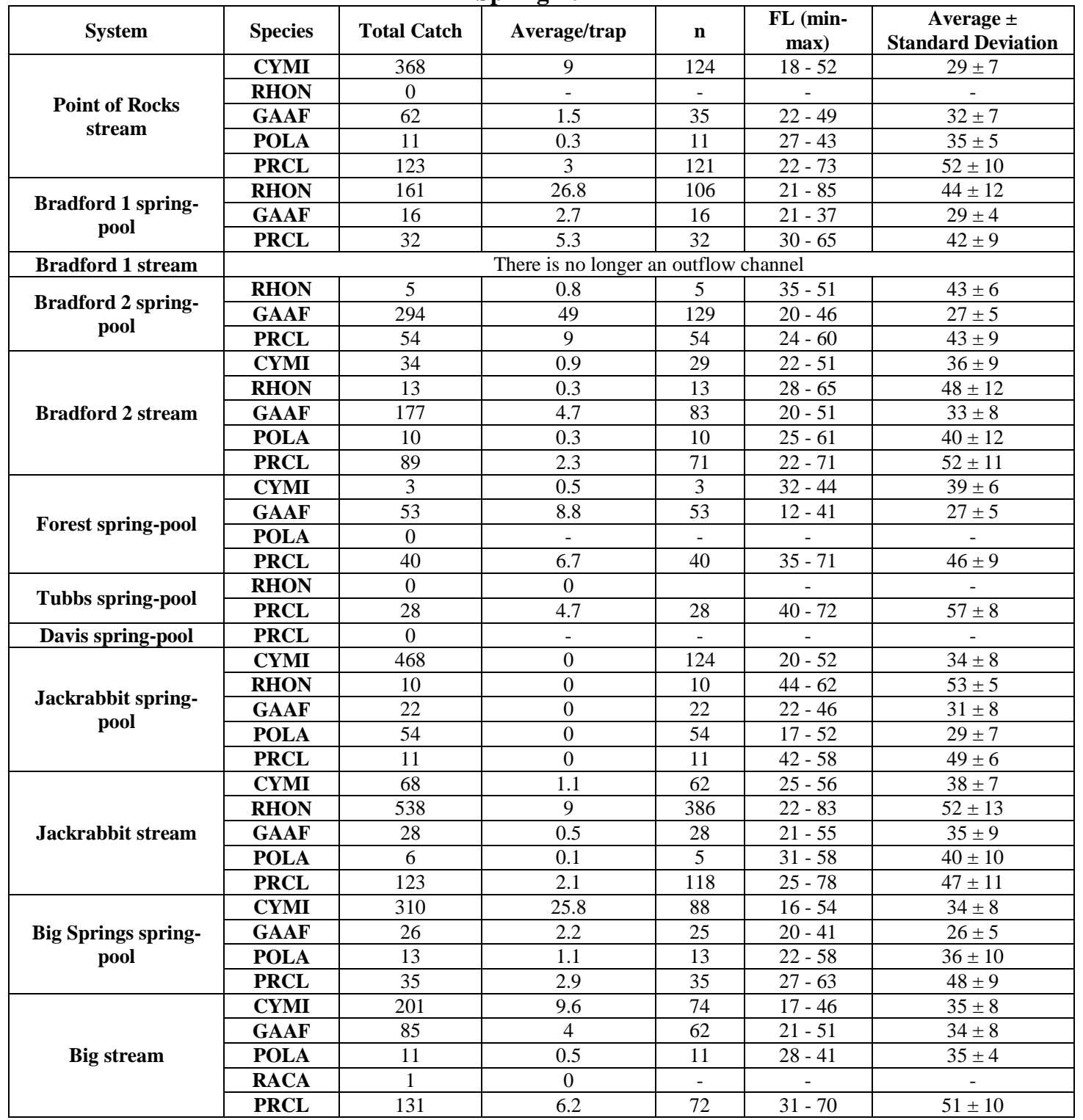


Publishing support provided by the U.S. Geological Survey Publishing Network, Tacoma Publishing Service Center

For more information concerning the research in this report, contact the Director, Western Fisheries Research Center

U.S. Geological Survey

6505 NE 65th Street

Seattle, Washington 98115

http://wfrc.usgs.gov/ 
